\title{
هياكل صنع السياسة الخارجية الإماراتية
}

\section{المقدمة}

تستقطب دراسة هياكل صنع السياسة الخارجية اهتمام السياسيين والباحثين والاكاديميين على حد سواء-- ذلك ان تتابع الاحداث، وتطورها يؤكد الحاجة الى مزيد من الفهم الواعي والمخطط لفهم تصرف دولة ما باسلوب ومنهج معينين ازاء احداث معينة.

إذ من الصعب تفسير الاسباب التي تكمن وراء صدور أي قرار سياسي في المجال الخارجي فقد تتداخل التفسيرات بثقافات معينة أو ايدلوجيات معينة، لذا ينبغي ان تؤخذ بعين الاعتبار تشابك وتداخل العوامل المؤثرة في عملية صنع السياسة الخارجية. كمـا يصـعب وضـع تعريـف معين ومحدد للسياسـة الخارجيـة وصـوبة التوصـل الـى مجموعـة الابعـاد التي تتـدرج في اطارهـا والعلاقـة بينها، فالسياسـة الخارجيـة لا تتحدد طبقـا لتشريعات ملزمـة، كما هو الحال في السياسـة الداخلية، لكن يمكن التعرف عليها من خـلال مجموعة من المؤشرات التي قد تعطي نتائج متتاقضة تجعل من الصعب التعرف على حثيقة السياسة الخارجية للدولة. والسياسة الخارجية للدولة الواحدة تتفاوت بتفاوت مع من يتم التعامل معهم وتفاوت قضايا التعامل الخارجي. يمكن فهم السياسة الخارجية لدولة الإمارات العببية المتحدة من خلال اوضاعها الداخلية الايجابية، والفلسفة التي تتتهجها القيادة والتي بدورها تختار ما يلائمها من بين الاهداف فضلا عن الجوانب المتعلقة بالبيئة الاقليمية والدولية.

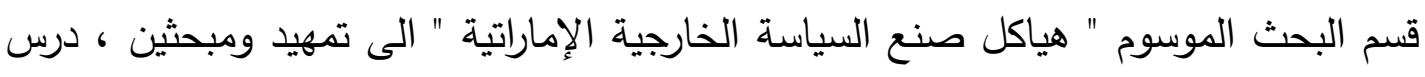
التمهيد(تأسيس ودستور دولة الإمارات العربية المتحدة) ، في حين كرس المبحث الاول لدراسة (الهياكل الرسمية لصنع السياسة الخارجية الإماراتية)، فيما تطرق المجحث الثاني الى (الهياكل غير الرسمية لصنع السياسة الخارجية الإماراتية ) • 


\section{تمهيد : تأسيس ودستور دولة الإمارات العربية المتحدة أولآ : تأسيس دولة ألامارات}

تقع دولة الإمارات العربية المتحدة بين خطي الطول 51 درجة و 31.56 درجة

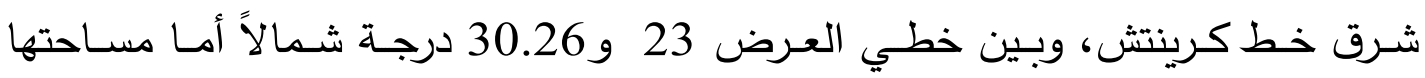

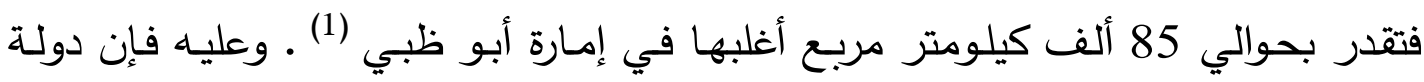

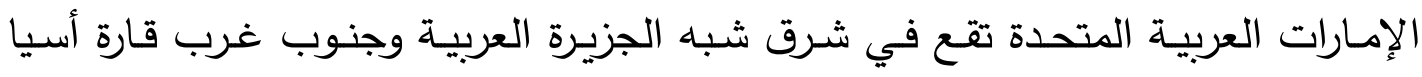
ومطلة على الثـاطيء الجنوبي للخليج العربي، لها حدود بحريـة مشتركة من الشمال

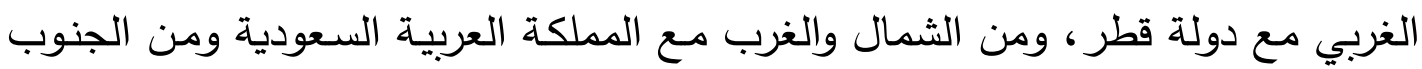
الشرقي مع سلطنة عمان (2 ).

يعد موقع الدولة موقعاً استراتيجياً مهما من الناحية الاقتصـادية وذلك لاستغلال

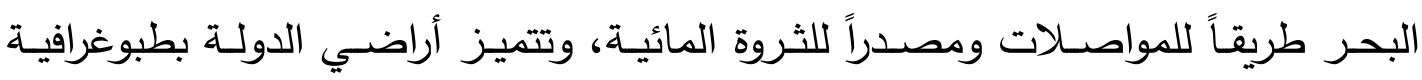
مزدوجة تتكون من أراضي جبلية وسهلية منخفضة (3) تتكون الدولة من سبع إمارات هي: أبو ظبي، دبي، الثـارقة، عجمان، الفجيرة، دانه

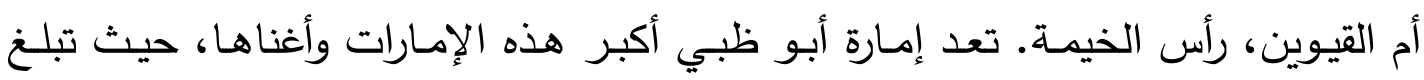

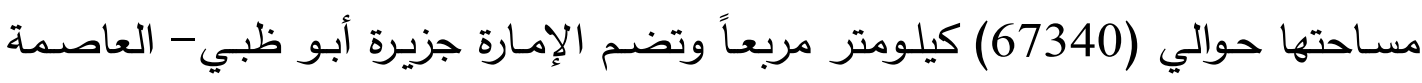
الاتحاديـة- وكذلك المنطقـة الثـرقية وعاصـمتها العين والمنطقـة الغربيـة وعاصـمتها

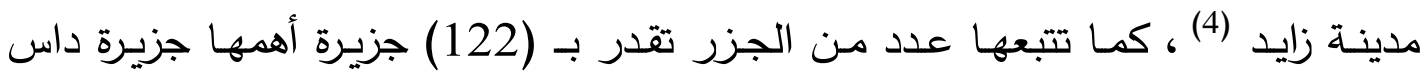
النفطية، والتي تقع إلى الثمال من جزيرة أبو ظبي على بعد (100) ميل منها (5) .

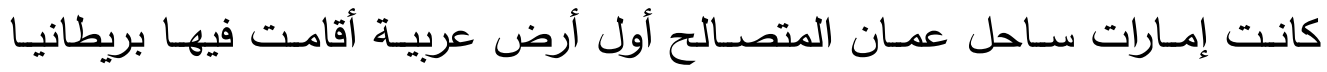
نفوذها-منذ عام 1820- وآخر أرض عربيـة غربت شمس السيطرة البريطانيـة عنها

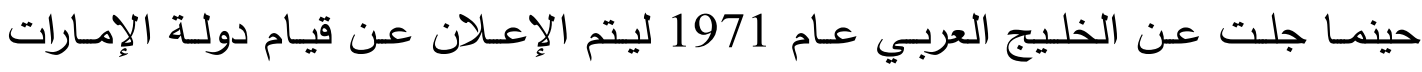
العربية المتحدة في الثاني من كانون الأول عام 1971. 
حرص الاتحاد على تحويل الاتحاد القبلي إلى دستوري من خلال إرساء قواعد

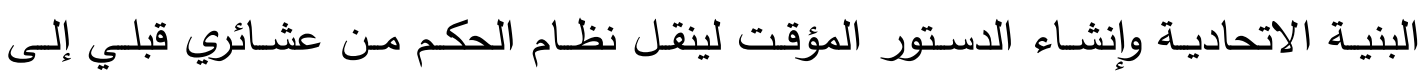

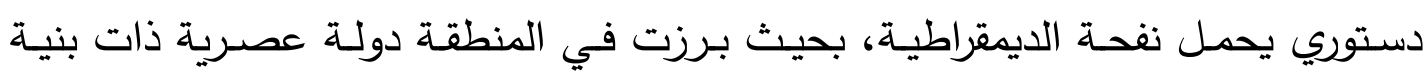

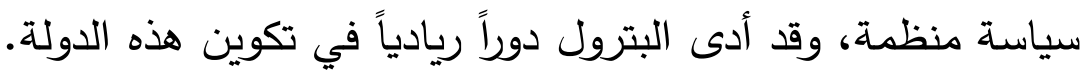

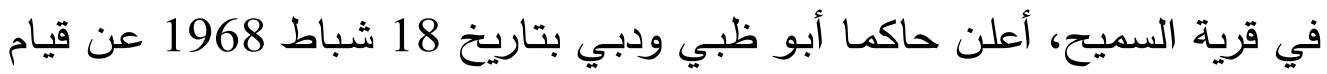

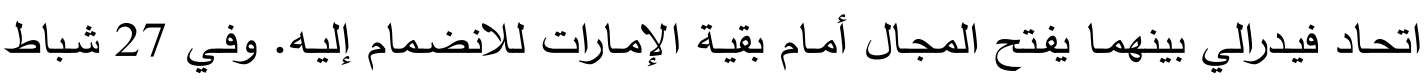
1968 تم الإعلان عن قيام اتحاد الامارات التسع (يضم الإمارات السبع المكونة حالياً

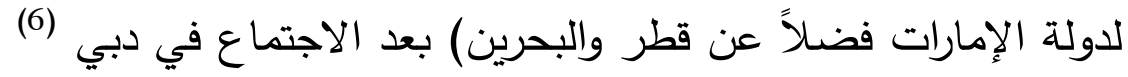

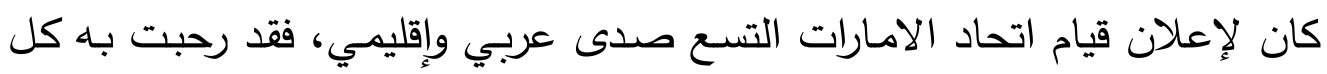
من السعودية والكويت (7) ، إما إيران فقد كانت تنظر بتراتب الإنب إلى ما يدور في الجانب الغربي من الخليج العربي التي كانت لديها مطامع في الجزر العمانية والبحرين في لي لئي

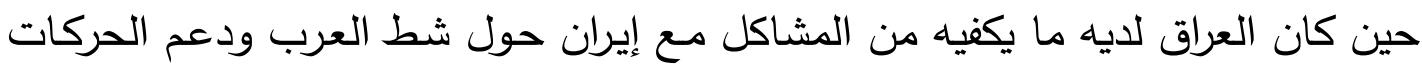
المعارضة الإيرانية(8) إن النزعة الذاتية المحلية عند حكام الإمـارات الصغيرة التي لا ترغب في إذابة

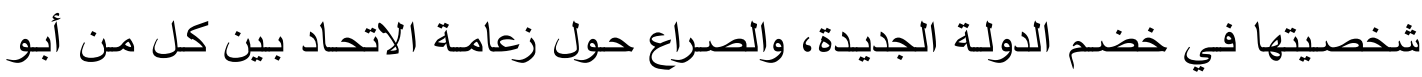
ظبي وقطر والبحرين جعل الأولى تفضل اتحاد الامـارات السبع على اتحاد الإمارات

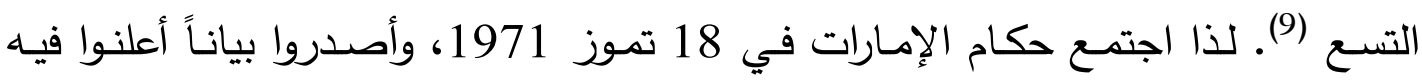
قيام دولـة اتحاديـة جديدة من إمـاراتهم باسم الإمـارات العربيـة المتحدة، وأقروا دستوراً

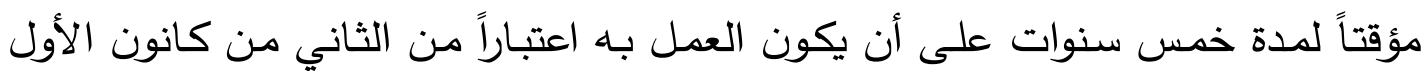
عام 1971(10) ـ وفي حينها تم انتخاب الشيخ زايد بن سلطان ال نهيان رئيساً للإتحاد

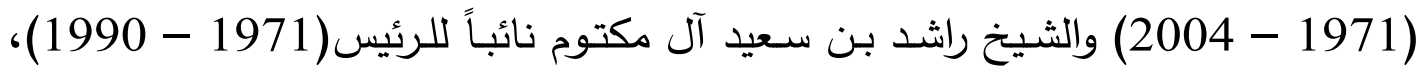

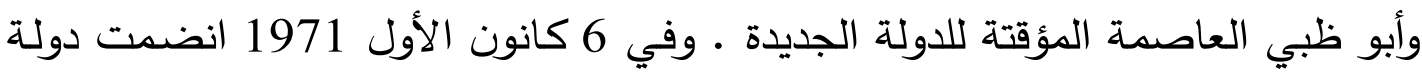
الإمارات العربية المتحدة لجامعة الدول العربية وفي 10 كانون الأول 1971 قبلت في

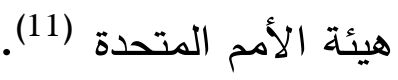
كان لسيادة المظـاهر السياسية والاقتصـادية لإمـارتي أبو ظبي ودبي الأثر في اختيار الرئيس ونائب الرئيس ورئيس الوزراء، كما أنعكس في تكوين الوزارات الهامة 
كالدفاع والمالية والداخلية والثؤون الخارجيـة وشؤون العلاقات الاتحادية هي مشـاركة بين هذين العضوين (12) . لقد حدثت ثلاث متغيرات اقتصادية واجتماعية وسياسية ساعدت في نشوء دولة الإمـارات العربيـة، حيث أدى ظهور النفط إلى ايجاد حافز جوهري في قيام الاتحاد،

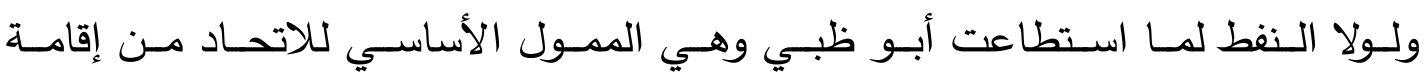
المؤسسات الاتحادية (ففي عام 1962 صدرت أول شحنة من النفط الخام، وفي آب 1966 اختير الثيخ زايد حاكماً لابو ظبي فقام ببرنامج ضخم لبناء المدارس والإسكان

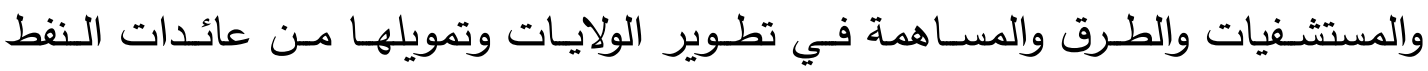

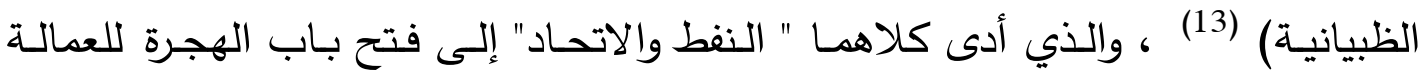
الوافدة(14) -وهي المتغير الثالث- من أجل بنـاء مجتمـع متحضر اقتصـاديا وتربوياً

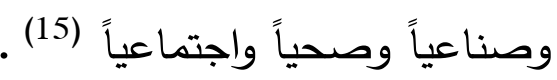
أن مـا قدمـه الثـيخ زايــ من خدمات ومـا تمتع بـه مـن سمات شخصية، كـان السبب في اختياره رئيسـاً لدولـة الإمـارات عـام 1971، ووفقـاً لإجراءات دستورية تم الاتفاق عليها في 7 تشرين الثاني 1981 من قبل المجلس الأعلى للاتحاد على تمديد العمل بالدستور المؤقت لمدة خمس سنوات أخرى، كذلك تم تجديد انتخاب الثيخ زايد بن سلطان آل نهيان رئيساً للدولة، والثيخ راشد بن سعيد آل مكتوم نائباً للرئيس (16). لقد سمح الدستور التصديق على رئاسة الثيخ زايد ال نهيان من جديد وساعده

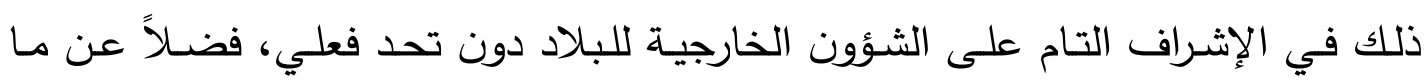
خوله له الدستور من صلاحيات تتعلق بالسياسة الخارجية، حسب البند (9) من المادة (54) من الدستور (17) . والتي تتص على ان رئيس الاتحاد "يمثل الاتحاد في الداخل وتجاه الدول الاخرى، وفي جميع العلاقات الدولية"(18). سعت دولة الإمارات خـلال السنوات الثلاثة الأولى من عمر الإتحاد إلى تدعيم مركزها العربي والاقليمي والدولي، ولقد كان لها دور نشط في هيئة الأمم المتحدة في مقدمـة ذلك توضيح حقيقـة مشكلة فلسطين وعدالــة قضـيتها وشـاركت في مؤتمرات جامعة الدول العربية وتدعيم المؤتمرات الإسلامية (19) . 
حاولت دولـة الامـارات العربيـة المتحـدة في سياستها الخارجيـة ان توازن بين إمكاناتها وقدراتها وأوضاعها الداخلية، وبين البيئة الخارجية، فانتهجت سياسة مرنـة في علاقاتها الخارجيـة، وعملت على تسوية خلافاتها بـالطرق السلمية وحاولت توظيف تهن قدراتها الاجتماعيـة والاقتصـادية ، وتركزت المحددات الأساسية في صياغة السياسـة الخارجية الإماراتية بعدة عوامل يمكن أجمالها بـ (20) :

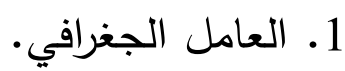

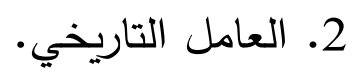
3. التركيبية الاجتماعية والاقتصادية. 4. القدرات العسكرية . 5. البنية السياسية لدولة الإمارات. 6. دور الصحف ووسائل الإعلام.

حيث تحتل دولة الإمارات العربية المتحدة موقع القلب في الخليج العربي، وتمتد سواحلها المطلة على الخليج العربي مسافة (644) كليو متر من قاعدة شبه جزيرة

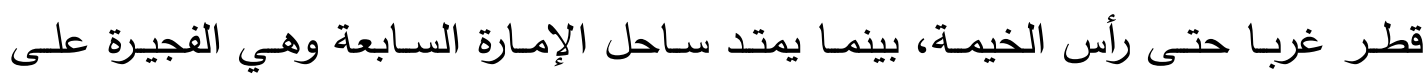

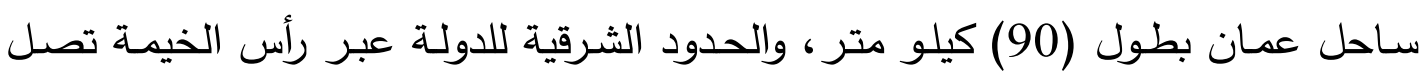
الى مشارف مضيق هرمز (21) . وقد ادى أكتثـاف الـنفط وتصـديره بكميـات كبيـرة في دولــة الإمـارات العربيـة المتحدة الى تطور كبير في البنيان الاقتصـادي والاجتمـاعي وترتب على ذلك عدة نتائج هامة منها(22):أولاً: ادت ملكية الدولة للثروة البترولية الى تعاظم دور القطاع العام ودور الدولة في عملية التنمية. ثانياً: سمحت عوائد البترول المطردة الازدياد لدولـة الامـارات ان تأخذ بسياسـة (الدفعة القوية) في التتمية بدلاً من سياسة التدرج التي تأخذ بها عادة البلاد الاخذة في النمو وذات العجز في ميزان المدفوعات. 
ثالثاً: ادى الاعتماد بصيغة اساسية على البترول الى اندماج الاقتصساد الوطني

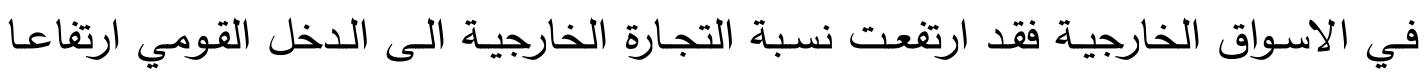
كبيراً.

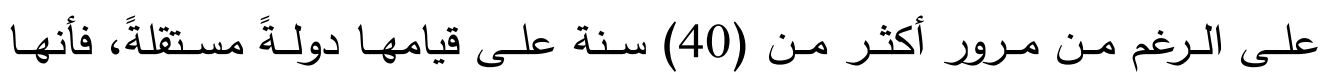

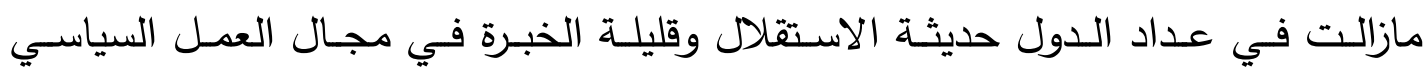

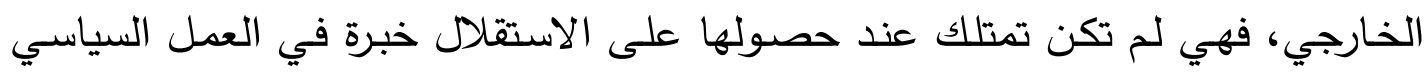

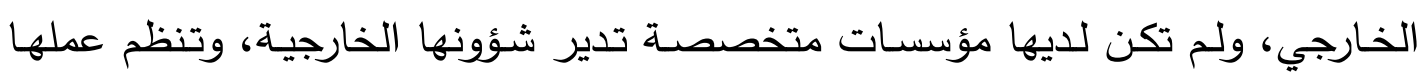
الدبلوماسي، ترتب علاقاتها وارتباطاتها بدول العالم، ولم تكن تتوافر للدولة الاتحادية الجديدة -آنذاك- كوادر دبلوماسية محنكة وخبيرة ومتدربة وقادرة على ترتيب أولويات

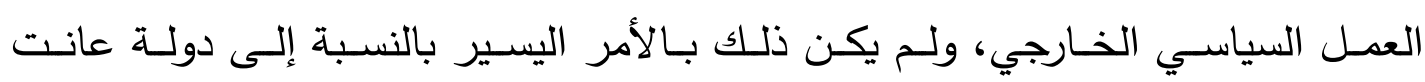
الاستعمار والانغلاق السياسي لأكثر من (150) سنة متواصلة.

\section{ثانياً : دستور دولة الإمارات}

تعني كلمة دستور في اللغة "الأساس أو البناء" والتكوين وهو مجموع القواعد

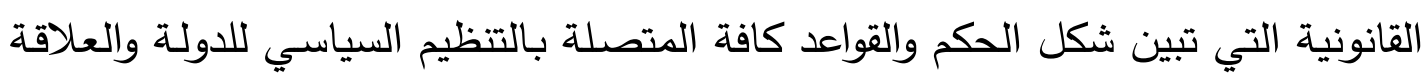

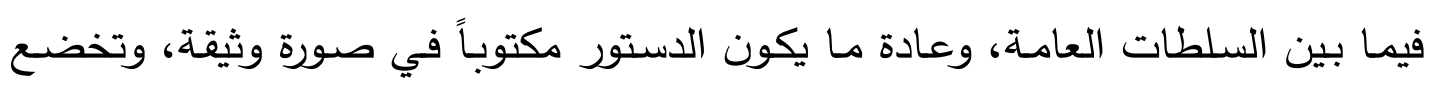

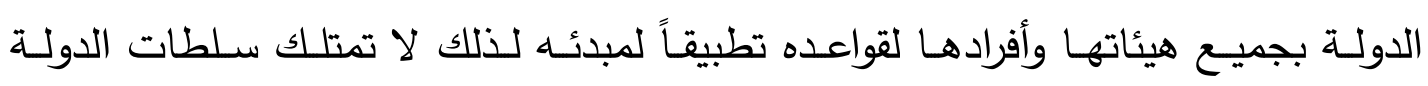

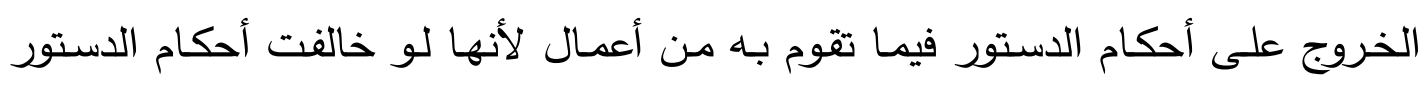

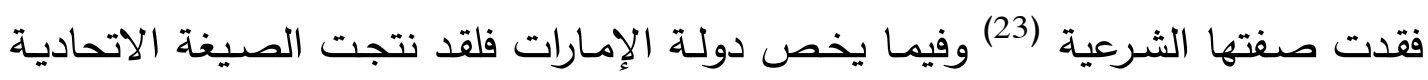
من معادلة صعبة جمعت بين الطموحات الكبيرة وبين الواقع، فبعد فشل اتحاد امارات

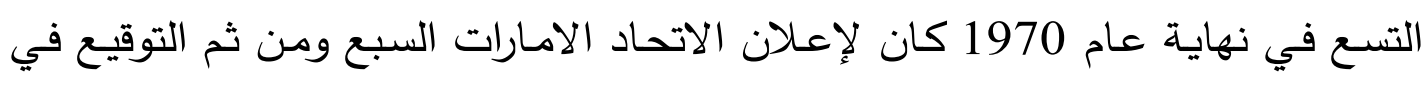

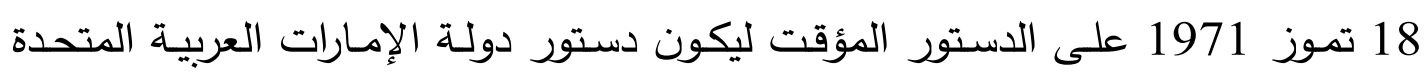
2

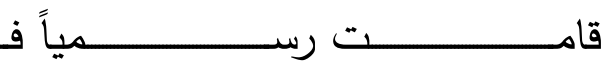
الت

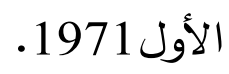

أن أول خصائص هذا الدستور هو دستور مؤقت وهذا واضتح من ديباجته التي ورد فيها ان الدستور يعمل به " إلى ان يتم إعداد الدستور الدائم" (24) . 
كـان الهدف مـن وراء وضـع دسـتور مؤقت، حددت مدتـه بخمس سـوات، هو التغلب على الآثار السلبية للصـراعات القبليـة التي كانت سـائدة انذاك. إن استمرار العمل به أكثر من أربع مدد، يوحي من ناحية ما بحدة الانقسامات السياسية السائدة بين الإمارات الأعضاء في الإتحاد، وإن الدستور الذي تم تبنيه لم يحقق الهدف منـه، في تحقيق الاندماج الداخلي وان بعض مواد الدستور ، قد عززت التراتبية في النظام

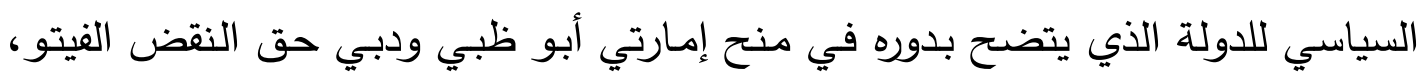
وغيب المشاركة السياسية الفاعلة، إذ يجمع المجلس الأعلى للإتحاد السلطتين التنفيذية

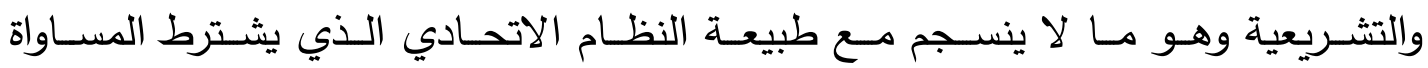
والديمقراطية لنجاحه (25). كـان الثـيخ زايدـ بـن سـلطان قد اصـدر قـراراً بـرقم (2) لسـنة 1975 ويقضـي

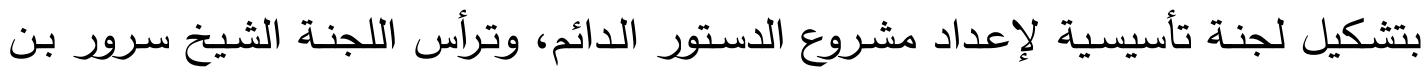
محمد آل نهيـان رئيس ديـوان رئيس الدولــة -آنـذالك- على ان تنتهي المـدة الدستورية الأولى سنة 1976، ليتم اعتماد الدستور الدائم، وقد أنجزت اللجنة التأسيسية عملها في 24 آيار 1976، وأعدت مشروع الدستور الدائم للبلاد وجاء بـ (162) مادة، وقد الند أحتوى على مبادئ دستورية جديدة لم تكن واردة بالدستور المؤقت (26).

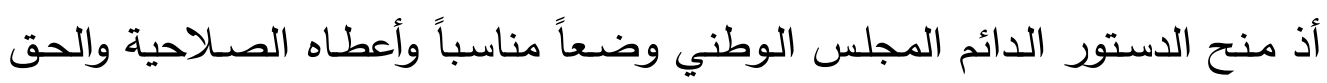

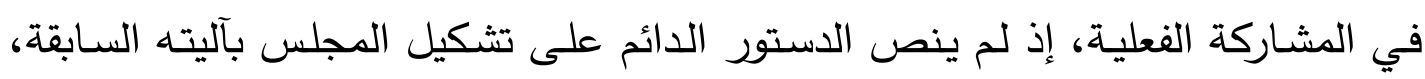
إنما نصت المادة (162) من الدستور الدائم على: (( يثكل المجلس الوطني لدولـة

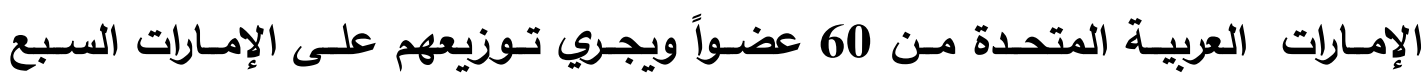
الأعضـاء بمراعـاة نسبة عدد المواطنين لكل إمـارة ... ))، إما فيما يخص الدستور

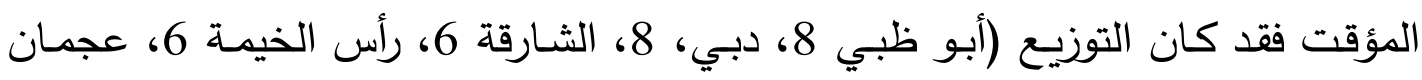
4، الفجرة 4، أم القيوين 4) (27)

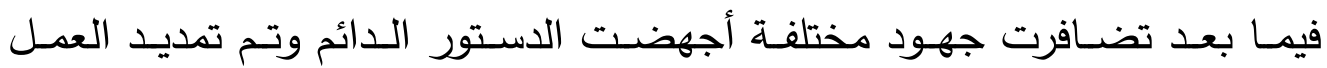

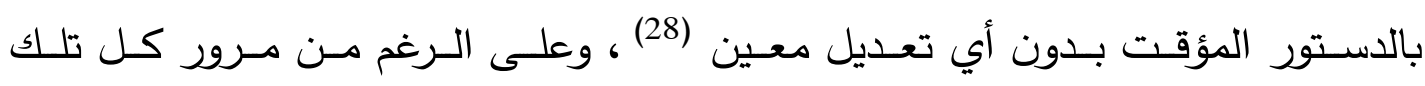
السـوات، فـان النظـام السياسـي للإمـارات غيـر متماسـك وان التــافس بـين الإمـارات

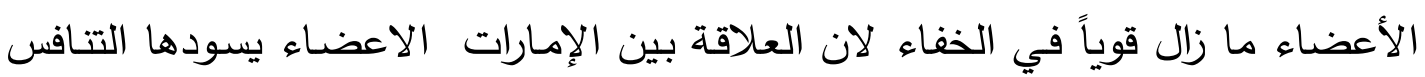


أكثر من التعاون، ففي حين رغب بعضهم في بنـاء العاصمة الاتحاديـة التي نص

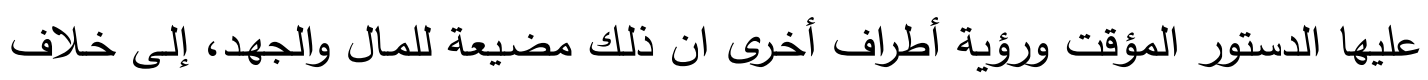
على بعض التشريعات الدستورية التي تمت منذ قيام الإتحاد والنظر إليها على أنها غير دستورية (29) ، وقد قرر المجلس الأعلى للإتحساد في اجتماعـهـ يـوم 20 أيسار

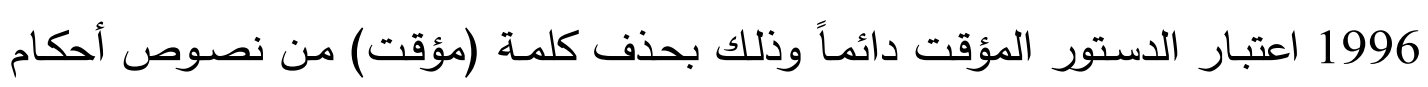
الدستور كما قرر ان تكون مدينة أبو ظبي عاصمة للدولة (30) .

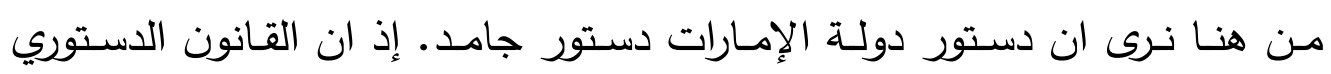

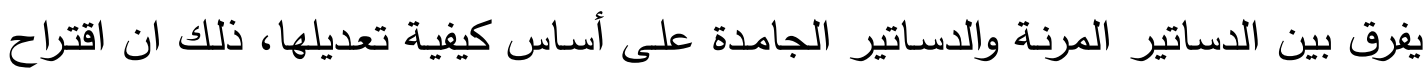

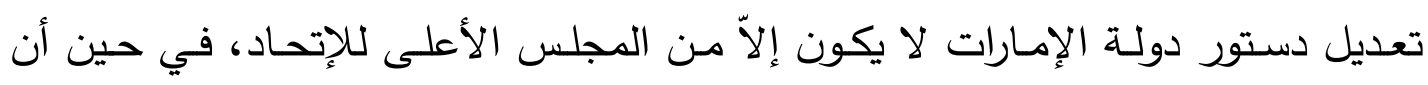

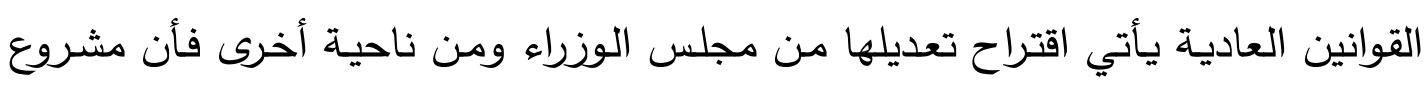

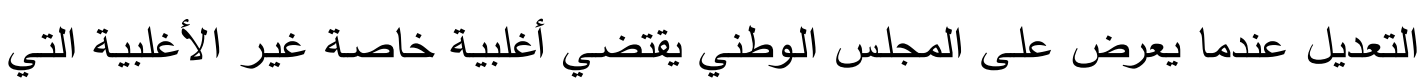
يقتضيها تعديل التشريع العادي حيث أقرت المـادة (144) من الدستور المؤقت الفقرة

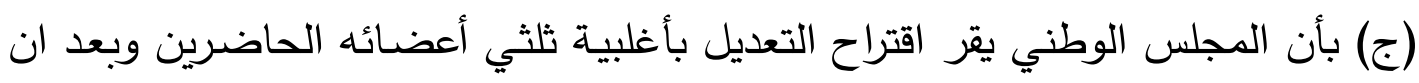

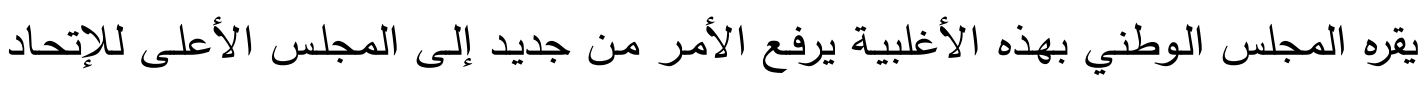

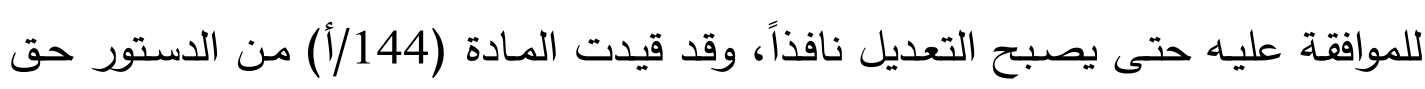

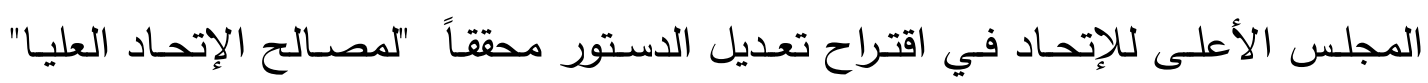

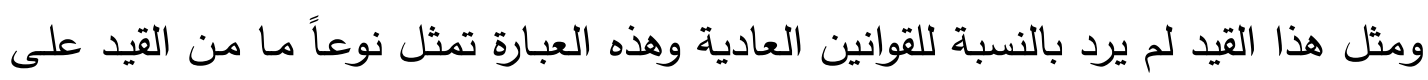
اقتراح تعديل الدستور (31) وكما هو معروف، فإن الإمارات تتميز بأنها دولة اتحادية ذات سيادة حسب ما

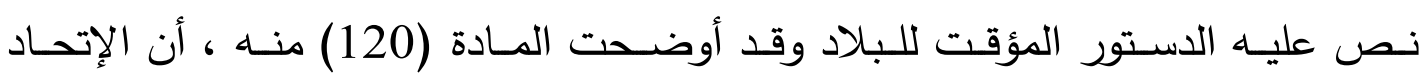

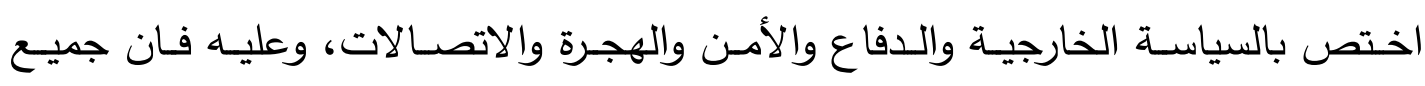

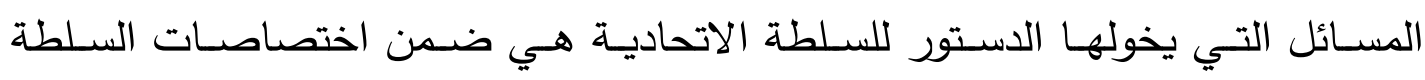

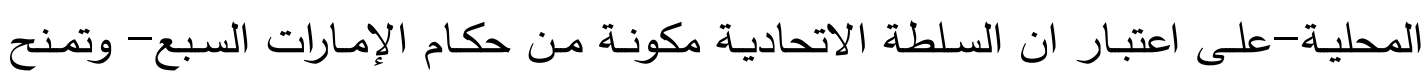
المادة (123) الإمارات الأعضاء الحق في توقيع اتفاقيات محدودة ذات طبيعة إدارية

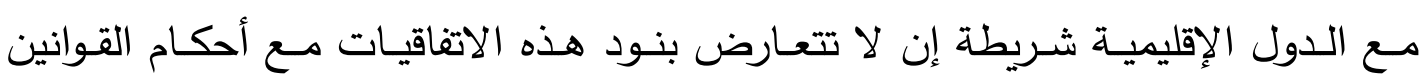

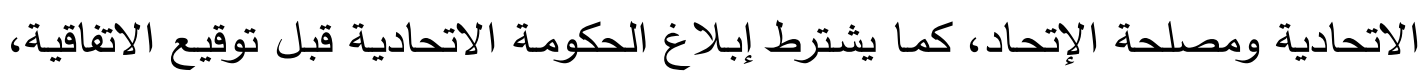


وفي حالة عدم موافقة الدجلس الأعلى للإتحاد يؤجل بحث القضية إلى اجتماع آخر ،

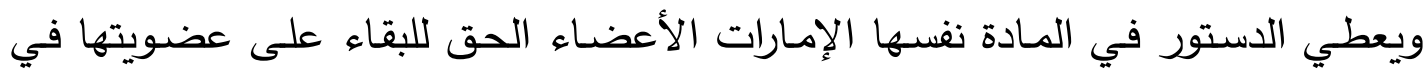

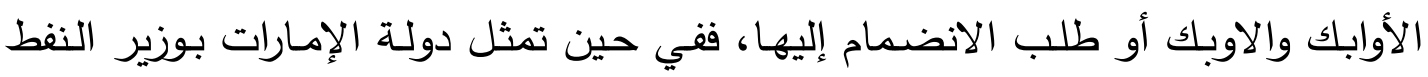

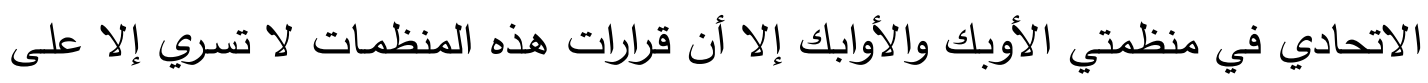

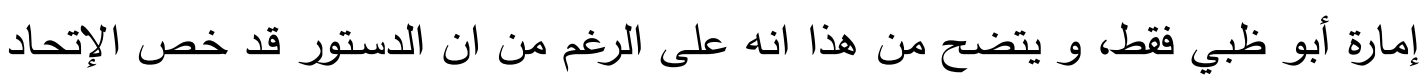

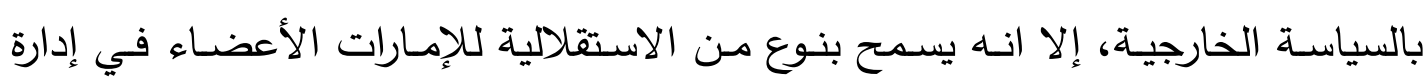

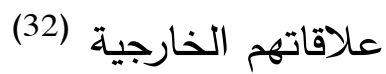
وعليه فقد نهج دستور دولة الإمارات العربية المتحدة في تحديده للاختصـاص

التتفيذي والتشريعي للسلطات الاتحادية أسلوبين هما: (33) 1

انفراد الإتحاد بالتشريع والتنفيذ في الثؤون الواردة بالمادة (120) من الدستور •

$$
2 \text { - 20 - 2 - الأسلوب الثاني:- }
$$

انفراد الإتحاد بالتشريع فقط في الثؤون الواردة بالمادة (121) من الدستور .

$$
\text { وكما موضح ادناه: }
$$

أ : انفراد الإتحاد بالتشريع والتتفيذ في المجاهاه

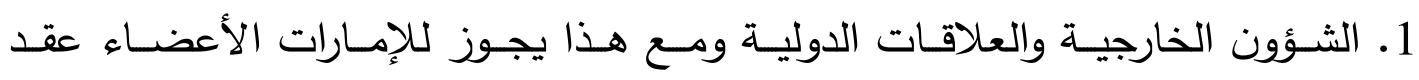

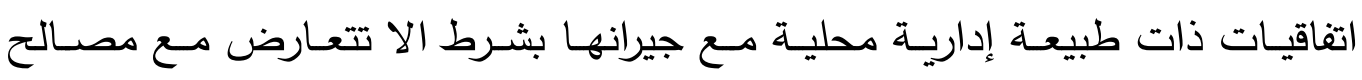

$$
\text { الإتحاد ولا مع القوانين الاتحادية. }
$$

2. حماية أمن الإتحاد مما يتهدده من الخارج أو الداخل.

3. الدفاع و القوات المسلحة الاتحادية.

4. شؤون الأمن والنظام والحكم في العاصمة الدائمة للإتحاد. 5. شؤون موظفي الإتحاد والقضاء الاتحادي. 6. مالية الإتحاد والضرائب والرسوم الاتحادية. 7. القروض العامة الاتحادية. 8. الخدمات البريدية والبرقية والهاتفية واللاسلكية. 
9. شـق الطـرق الاتحاديـة التي يقرر المجلس الأعلى انها طـرق رئيسـة وصـيانتها وتحسينها وتتظيم حركة المرور على هذه الطرق . 10. المراقبة الجوية وإصدار تراخيص الطيارات والطيارين. 11. التعليم. 11 12. الصحة العامة والخدمات الطبية. 13. النقد والعملة. 14. المقاييس والمكاييل والموازين. 15 . خدمات الكهرباء. 16. الجنسية الاتحادية والجوازات والإقامة والهجرة. 17. أملاك الاتحاد وكل ما يتعلق بها.

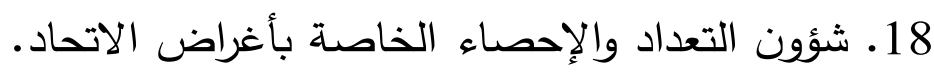
19. - الإعلام الاتحادي.

ب : انفراد الاتحاد بالتشريع على ان يناط للإمـارات التنفيذ ودون إخـال بما هو وارد في الأسلوب الأول وذلك في المجالات الآتية: 1. علاقات العمل والعمال والتأمينات الاجتماعية. 2. الملكية العقارية ونزع الملكية للمنفعة العامة. 3. ت تسليم المجرمين.

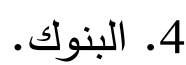

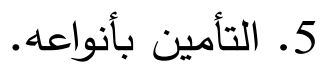
6. كماية الثروة الزراعية والحيوانية. 7. التشريعات الكبرى المتعلقة بقوانين الخبراء والمعاملات المدنية والتجارية والثركات والإجراءات أمام المحاكم المدنية والجزائية. 8. حماية الملكية الأدبية والفنية والصناعية وحقوق المؤلفين.

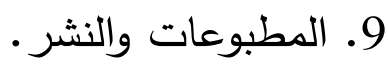
10. استيراد الأسلحة والذخائر . ما لم تكن لاستعمال القوات المسلحة أو قوات الأمن التابعة لأي إمارة. 
11. شؤون الطيران الأخرى التي لا تدخل في اختصاصات الاتحاد التنفيذية. 12. تحديد المياه الإقليمية وتتظيم الملاحة في أعالي البحار .

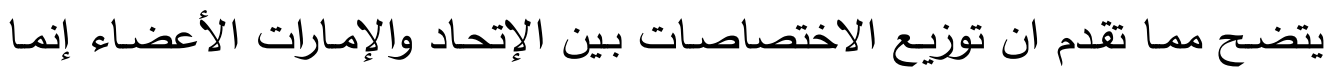

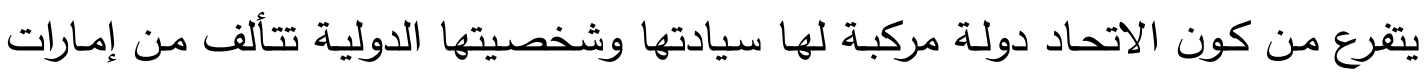

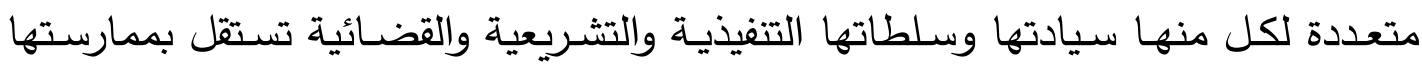
على أراضيها وسكانها خارج الإطار الذي ينفرد الاتحاد فيه بسلطاتها ومما لا شك فيسه ان هذا التوزيع في الاختصاصـات كمـا يراهـا بعض البـاحثين

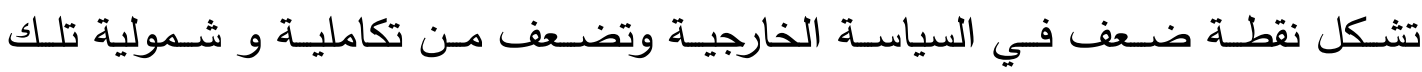
السياسة، ومن ثم تحد من قدرتها على الحركة والمبادرة في الثؤون الخارجية والدولية وتؤثر في رسم السياسة الخارجية للدولة سلباً لما نص عليه الدستور من بعض ولى مظاهر الاستقلال الخاصة بكل إمارة ومن أهم الاستثناءات(34) :

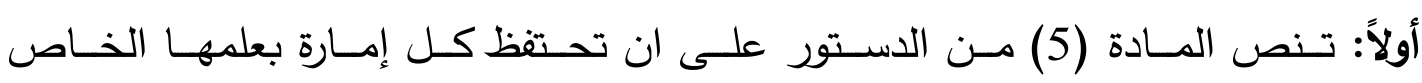
لاستخدامه داخل إقليمها. ثانياً: تنص المادة (23) من الدستور على ان "الثروات والموارد الطبيعية في كل إمارة

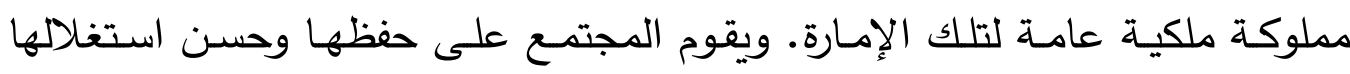
لصالح الاقتصاد الوطني".

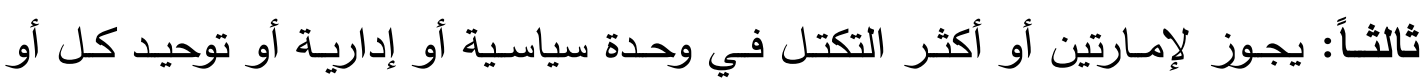

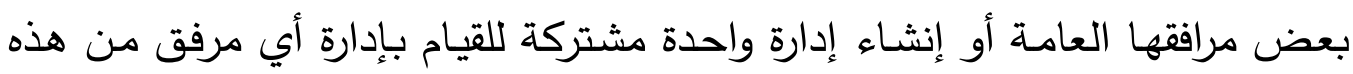

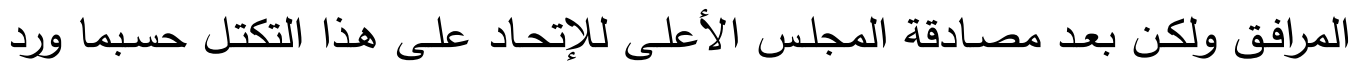

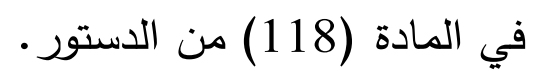

رابعـاً: تعطي المـادة (142) الحق لإمـارات الاتحـاد في إنثـاء قوات مسلحة محليـة

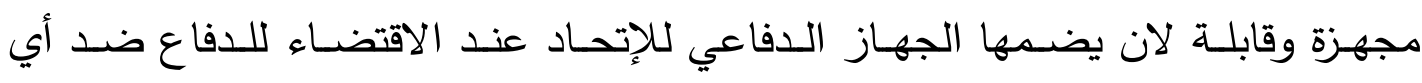
عدوان خارجي.

إن ظـاهرة احتفاظ كل إمـارة بسيادتها تترك تأثيرا في مسـار السياسـة الخارجيـة

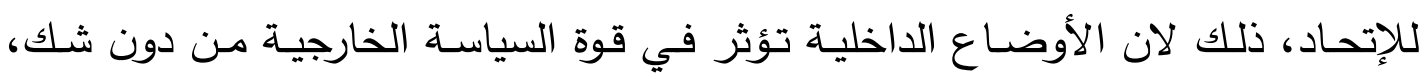
فعلى سبيل المثال فأن ما نصت عليه المادة (23) من الدستور حول ملكية كل إمارة 
لمـا تحويـه من ثروات وموارد طبيعيـة يؤثر في قدرات الإتحاد على تصريف شؤون

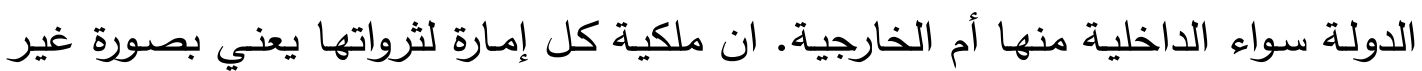

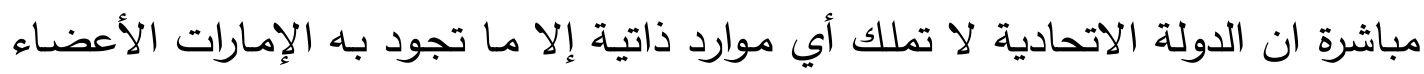

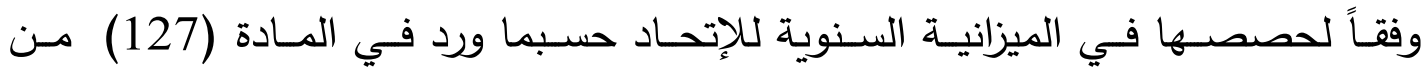
الدستور والتي تشير الى " تخصيص الامسارات الاعضساء في الاتحاد نسبة معينة من

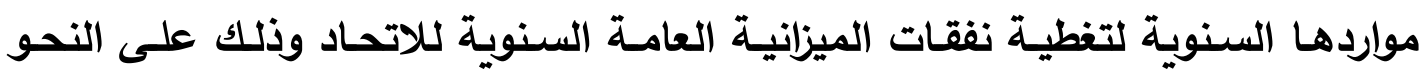

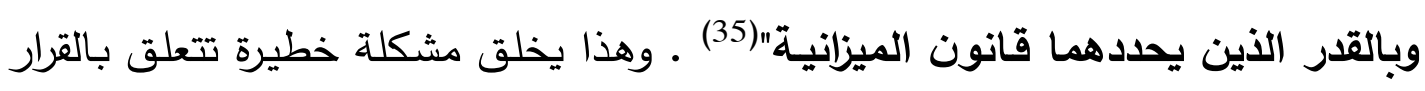
والإمكانات المادية للدولة الاتحادية ومن ثم ينعكس على دورها في المجال الخارجي .

\section{المبحـث الاول : ألهياكـل الرسـمية لصـــع السياســة الخارجيـة الإماراتية الميت}

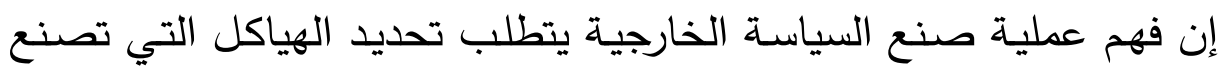

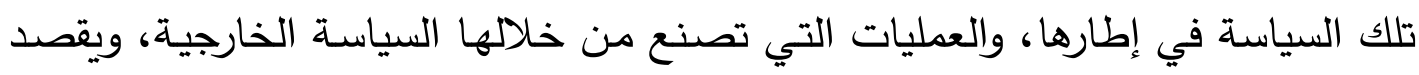

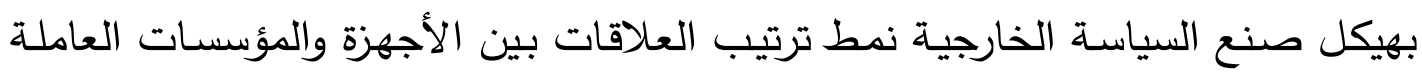

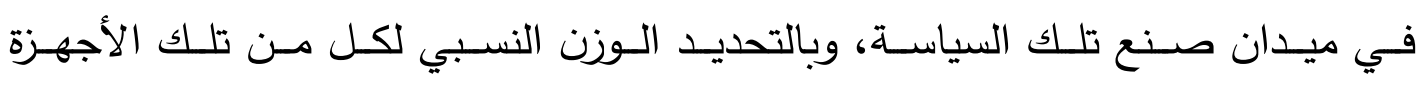

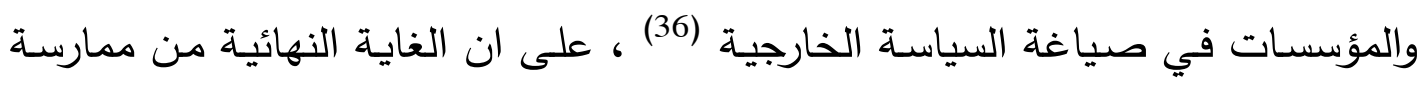
السياسية بشكل عام هو تحقيق أهدافها كما يرسمها المشرع أو صانع القرار .

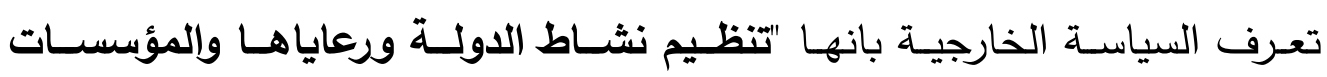
التابعة لسيادتها مع غيرها من الدول والتجمعات الدوليـة وتهدف السياسـة الخارجيـة

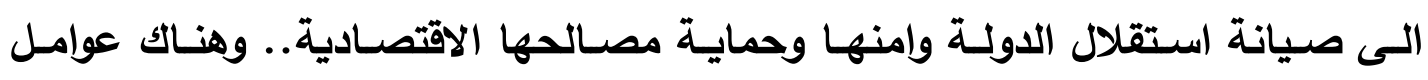

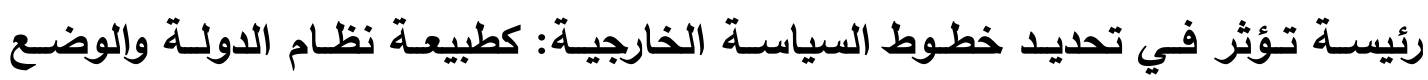

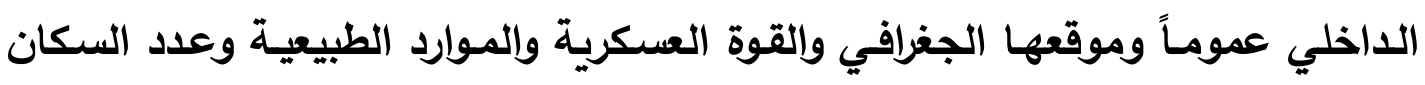

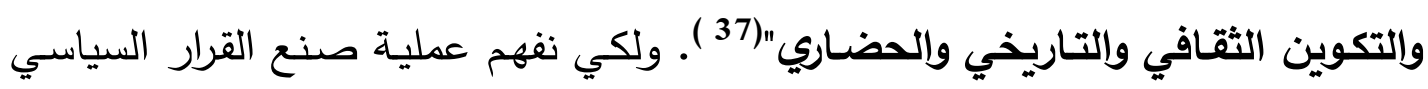
يتطلب ذلك توضيح الهياكل المساهمة فيه سواء كانت هياكل رسمية أم غير رسمية.

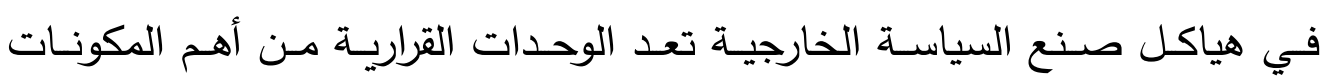

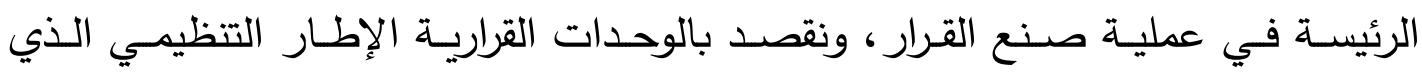
تتفاعل فيه أفكار صانعي القرار ويتم فيه اتخاذ القرارات المهمة باعتبارها هي المسؤولة 
عن تنظيم علاقة هياكل النظام السياسي فيما بينها من جهة والنظام السياسي عموماً

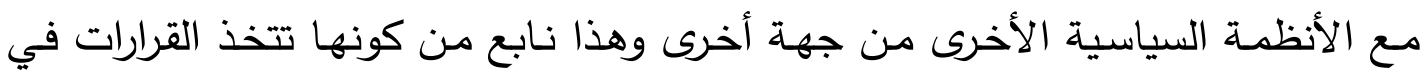

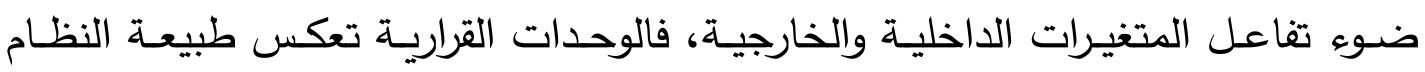
السياسي الذي يحدد إطارها المتلائم مسع طبيعة هذا النظام وعقيدته ورؤيته والهيكل المؤسساتي العام الذي يتحرك داخله فهي تختلف من ناحية الثكل والمضمون وتختلف من حيث السعة وحدود المناقثـة المسموح بها في النظم المفتوحـة عنهـا في النظم

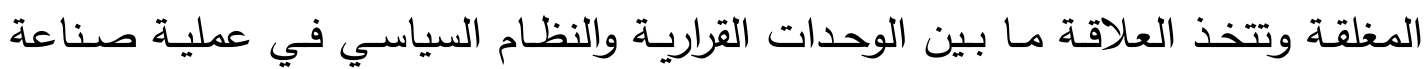
القرار السياسي ثلاثة أشكال من العلاقة وهي (38): 1. علاقة خضوع تامة للنظام السياسي أو للحاكم وتتطبق هذه العلاقة على الأنظمة الثمولية أو الأنظمة غير الديمقراطية.

2. علاقـة اسـتقلال أي تمتع الوحـدات القراريـة بصـلاحيات واسـعة مصـدرها النظــام السياسـي لكن هذا النوع غير فعـال في عمليـة صنع القرار السياسـي اذ يتم فيـه اتخـاذ قـرارات بمعزل عـن النظـام السياسـي بسـبـ ســـية العلاقـات فيمـا بـين الوحدات القرارية والنظام السياسي. 3. علاقة تفاعل وانسجام بين الوحدات القراريـة والنظام السياسي انطلاقاً من وضوح

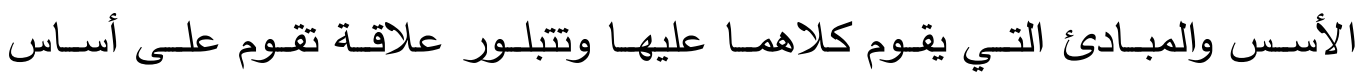

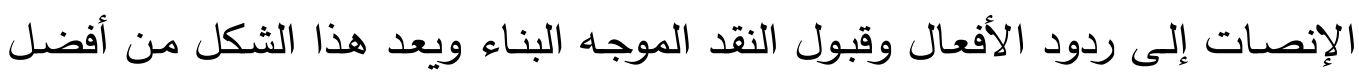
الأنواع ويوجد عادة في الأنظمة الديمقراطية.

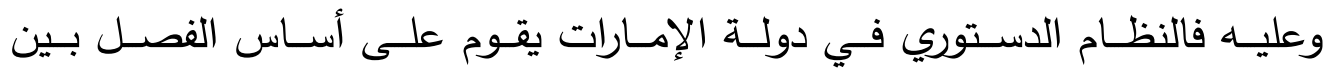
السلطات، وعلى وفق مـا حدد في الباب الرابع من المـادة (45) من الدستور الذي لإلي ينص على: "تتكون السلطات الاتحادية من المجلس الأعلى للاتحاد ورئيس الاتحاد ونائبه، ومجلس الوزراء الاتحادي، والمجلس الوطني الاتحادي، وإلقضاء الاتحادي"

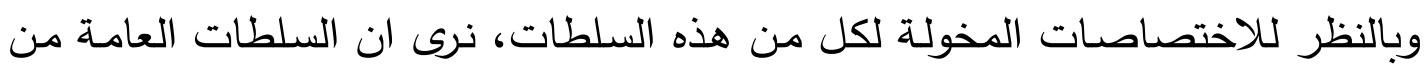
الاتحاد تتمثل في الواقع في ثلاث سلطات (39): 
أولآ : السلطة التشريعية

تعد السلطة التشريعية من أهم السلطات وأخطرها اذ تقوم بسن وتشريع القوانين وتعتمد في صياغة القوانين على فقهاء القانون وبالطبع يجب ان تكون لكون هذه القوانين

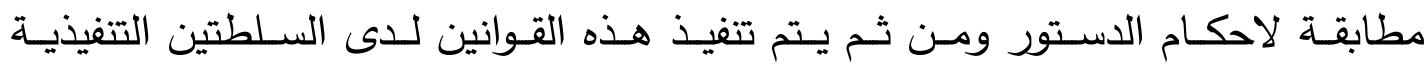

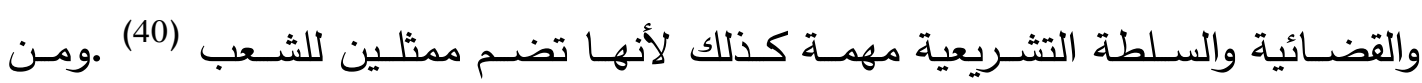
واجبات السلطة التشريعية: 1- سن القوانين حيث يمر القـانون بعدة مراحل هي الاقتراح والمناقشــة والتصـويت والتصديق والإصدار والنثر لكي يتعرف عليه أفراد الثعب. 2- إقرار الموازنة العامة ومراقبة صرف الأموال العامة.

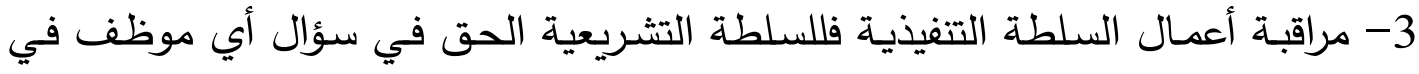
الدولة وإجراء تحقيق أو استجواب وحتى من حقها سحب الثقتة من الوزارة بأكملها إذا فاليا ارتأت بأنها حكومة تفتقر إلى الثرعية وبما إن المادة (68) من الدستور الإماراتي

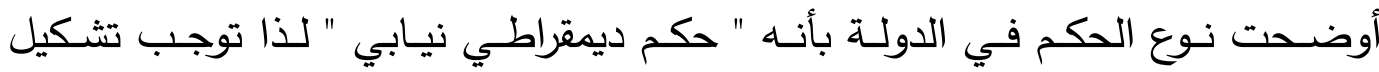

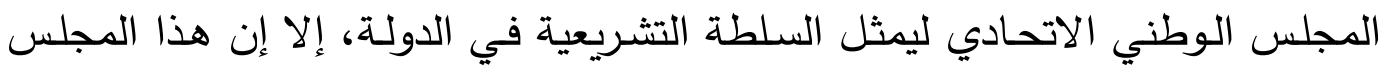

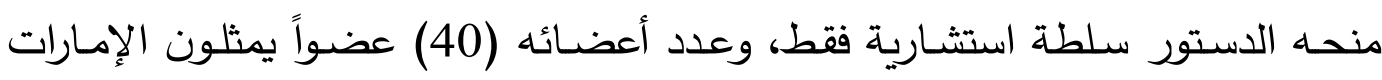
السبع التي تشكل الإتحاد (أبو ظبي، 8 مقاعد، دبي 8 مقاعد ، الشارقة 6، رأس الس التهات

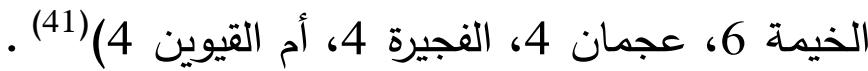
ولم يحدد الدستور في المادة (69) الطريقة التي يتم بها اختيار أعضاء المجلس

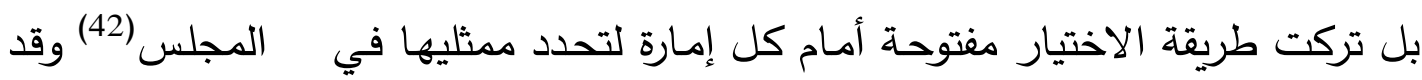

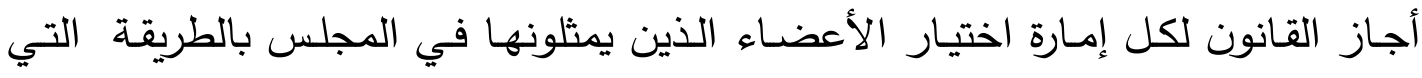
تراها الإمارة مناسبة ممن تنطبق عليهم شروط الإقامة في الإمارة التي يمثلوها وألا يقل

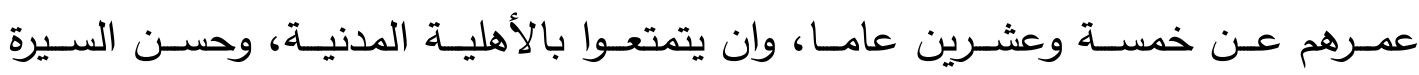
والسمعة، وبإلمام كاف بالقراءة والكتابة(43) .

يختار المجلس رئيساً من أعضائه، حيث منح الدستور المجلس الوطني سلطة مستقلة منها اختيار رئيسه بالانتخاب، فضلاً عن انتخاب نائب أول ونائب ثان لـها لهانه

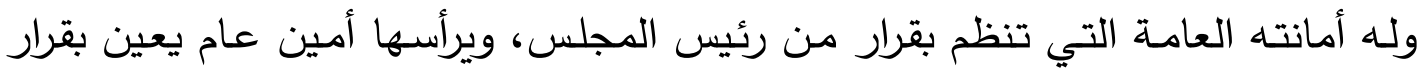


من رئيس الاتحاد، وللمجلس السلطة المطلقة في وضـع لائحته الداخلية، ومما عزز

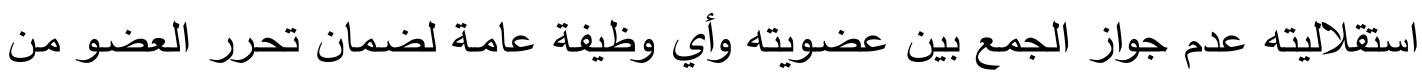

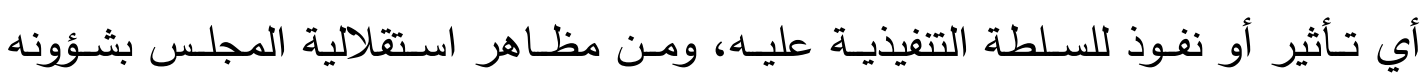
انفراده بالفصل في الطعون التي تقدم في صحة نيابـة أعضائه، وفي طلبات إسقاط

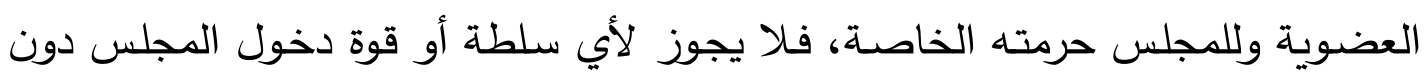
أذن رئيسـ. ويتمتع أعضاؤه بحصانه نيابية ضد جرائم الرأي (44). حسب المادة (81) من الدستور ، والتي تنص "لا يؤاخذ اعضـاء المجلس عما يبدونـه من الافكار والاراء في اثناء قيامهم بعملهم داخل المجلس أو لجانه". ومن اختصاصات المجلس الوطني الاتحادي (45) :

1. مراجعة مشروعات القوانين المالية قبل رفعها إلى رئيس الاتحاد 2. النظر في مشروع قانون الميزانية العامة للاتحاد. 3. تقوم الحكومـة بإبلاغـه بالمعاهدات والاتفاقيـات الدوليـة التي تعقدها مـع الدول

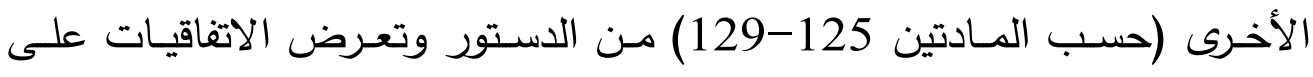
المجلس على شكل قوانين اتفاقيات من أجل مناقشتها وليس إقرارها. 4. مناقشة الموضوعات العامة المتعلقة بشؤون الإتحاد.

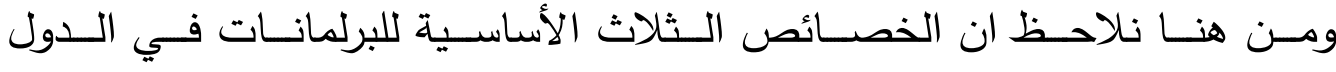

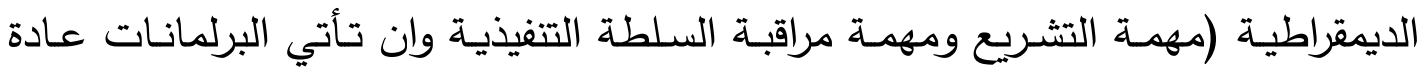

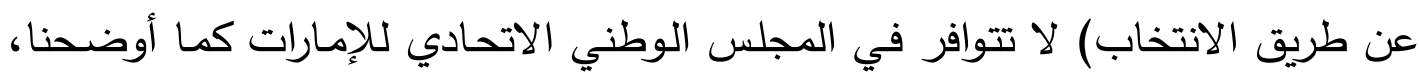

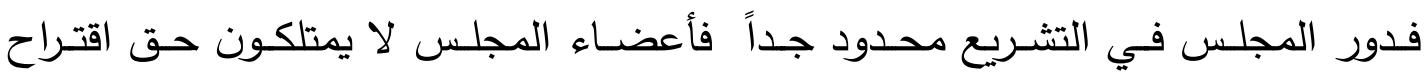

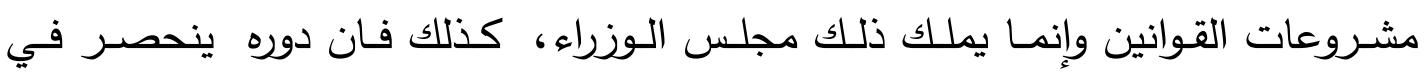
المناقشة ثم الموافقة فقط فمناقشة المجلس الاتحادي إذا انتهت إلى تعديل نص أو عدد لهد من النصوص في مشروع قانون ما فإن هذه التعديلات تخضع لموافقة رئيس الاتحاد

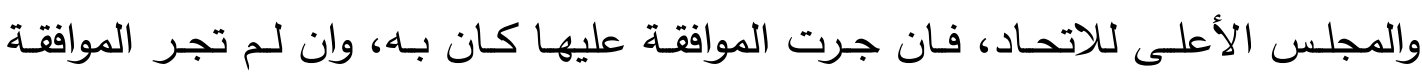
عليها أعيد المشروع للمجلس الوطني من جديد فان أصر المجلس على ما أدخله من تعديلات كـان للمجلس الأعلى للاتحـاد ان يصـرف النظر عن هذه التعديلات، وان 
يصدره رئيس الاتحاد- بعد موافقة المجلس الأعلى- على النحو الذي أقترحه مجلس الوزراء (46)

\section{ثانيآ: السلطة التنفيذية}

تعد السلطة التنفيذية القوة الأكثر نفوذاً في ميدان صنع السياسـة الخارجية، وينبع ذلك من عدة اعتبارات تقليديـة، وأخرى معاصـرة. فطبيعـة السياسـة الخارجيـة المتسمة بحالـة عدم اليقين وسـرعة التغير تتحو بالنظم السياسية إلى إعطاء السلطة التنفيذيـة

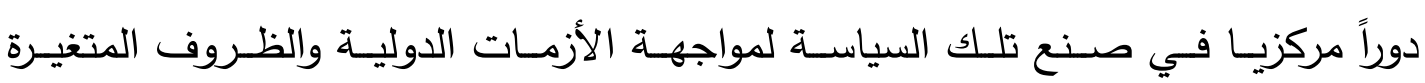

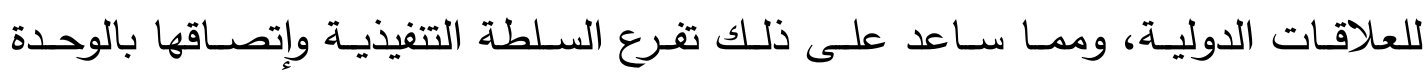

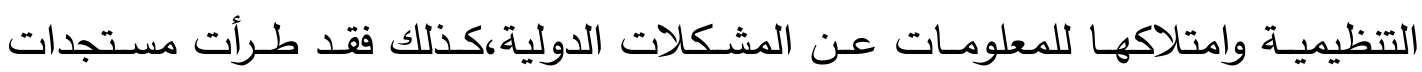
تطور تكنولوجيا الاتصسال، مدا مكن السلطة التنفيذية من سرعة التعامل مـع قضـايا السياسة الخارجية على حساب الدور الذي يمكن ان تمارسه المؤسسات الأخرى (47).

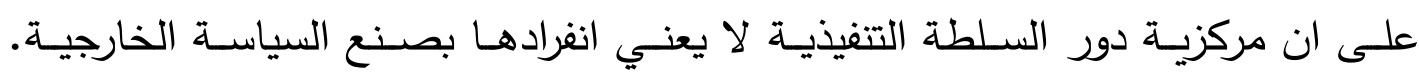

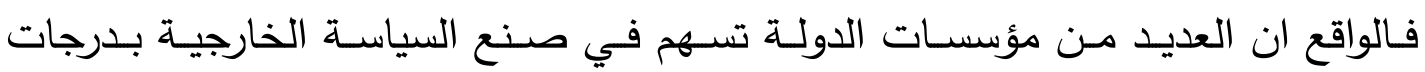

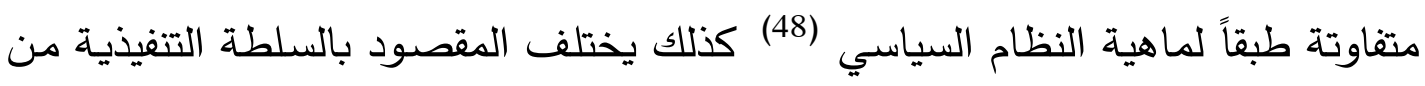
نظام سياسي إلى آخر، ففي نظام سياسي برلماني (كبريطانيا) يقصد بالسلطة التنفيذية

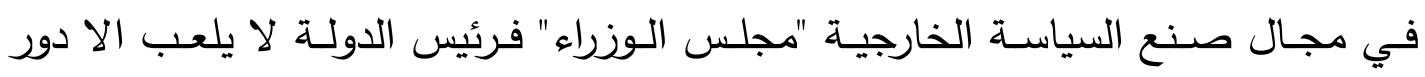
رمـزي في هذا المجـال ويقوم رئيس الـوزراء بالإثـراك مـع الـوزراء بعمليـة صـياغة السياسـة الخارجيـة. وفي النظـام السياسي الرئاسي مثل (الولايـات المتحدة الأمريكيـة)،

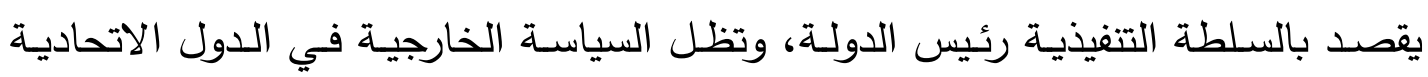

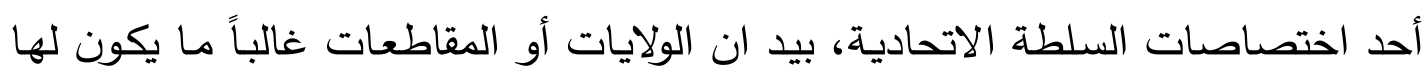

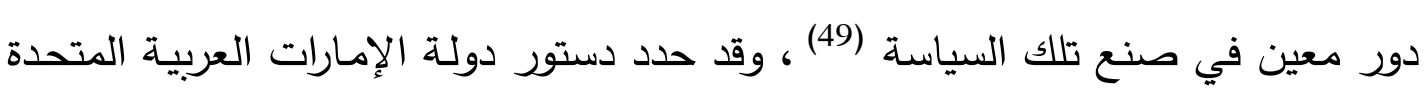
مسبقاً مكونات السلطة الاتحادية وحصرت بيد المجلس الأعلى للإتحاد ورئيس الاتحاد ونائبه ومجلس الوزراء.

أ: أمجلس الأعلى للإتحاد 
يعد المجلس الأعلى للإتحاد السلطة العليا في دولة الإمارات العربية المتحدة

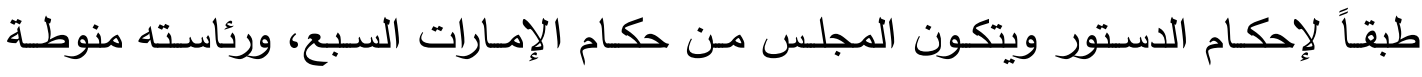

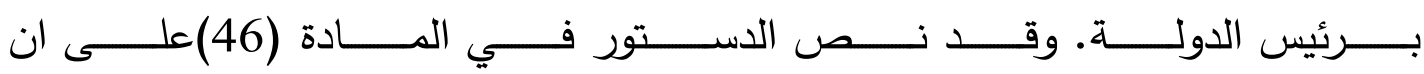
"المجلس الأعلى للاتحاد هو السلطة العليا فيـه، ويشكل من حكام جميع الإمـارات

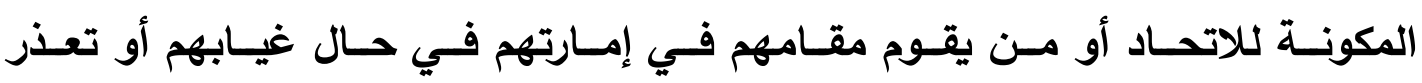

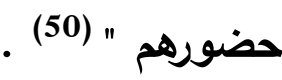
وقد حددت المادة (47) من الدستور مهام المجلس الأعلى للاتحاد وهي على النحو الآتي (51) :

1. رسم السياسية العامة في جميع المسائل الموكولة للاتحاد بمقتضى هذا الدستور

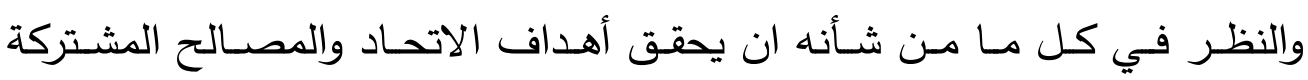

$$
\text { للإمارات الأعضاء. }
$$

2. التصديق على القوانين الاتحاديـة المختلفة قبل إصدارها، بــا في ذلك قوانين الميزانية العامة السنوية للاتحاد والحساب الختامي. 3. التصديق على المراسيم المتعلقة بأمور خاضعة بمقتضسى أحكام هذا الدستور لتصديق أو موافقة المجلس الأعلى وذلك قبل إصدار هذه المراسيم من رئيس بأيس الاتحاد.

4. التصديق على المعاهدات والاتفاقيات الدولية. ويتم هذا التصديق بمرسوم.

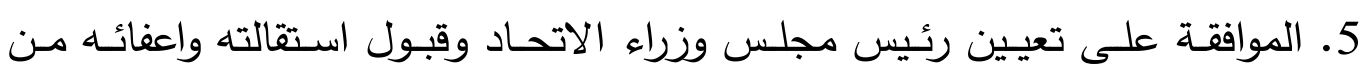

$$
\text { منصبا بناء على اقتراح رئيس الاتحاد. }
$$

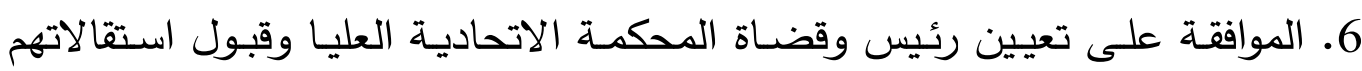
وفصلهم في الاحوال التي ينص عليها الدستور ، ويتم كل ذلك بمراسيم.

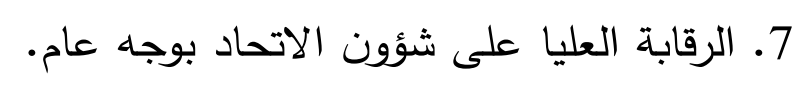

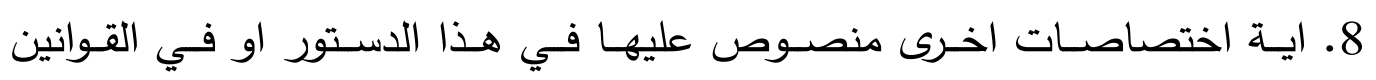

$$
\text { الاتحادية الته التهات }
$$

كما تجيز المادة (115) من الدستور للمجلس الأعلى ان يفوض رئيس الاتحاد

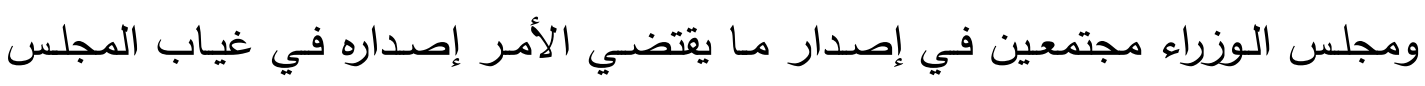


الأعلى من المراسيم التي يختص الهجس المذكور بالتصديق عليها على الا يثمل

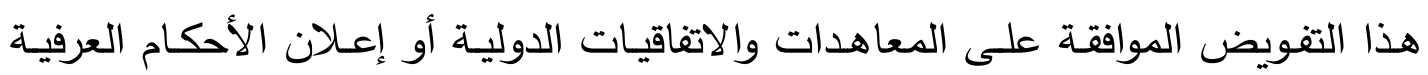

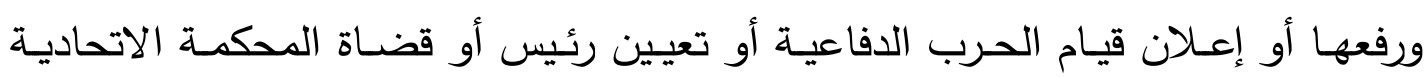
وعلى هذا فاختصاصات المجلس الأعلى على نوعين (52) :

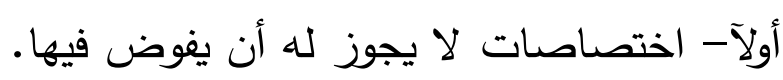

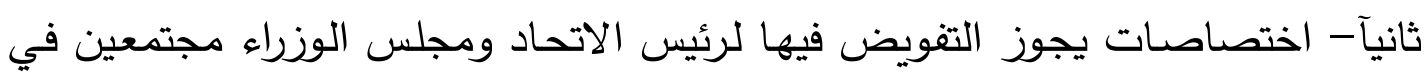
إصدارها.

\section{ب : رئيس الاتحاد ونائبه}

ينتخب المجلس الأعلى للاتحـاد مـن بين أعضـائه رئيس الاتحساد ونائبـه

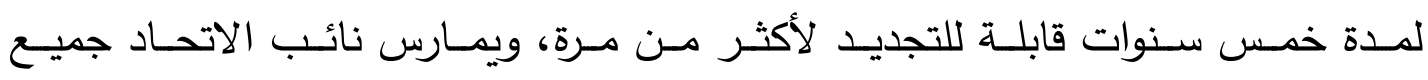

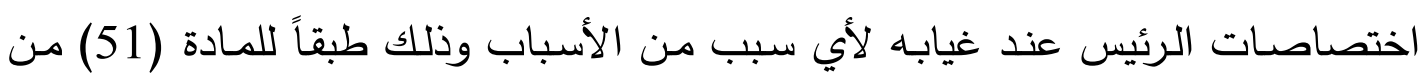
الدستور (53).

وقد منح الدستور في المادة (54) رئيس الدولة سلطات مهمة منها (54):

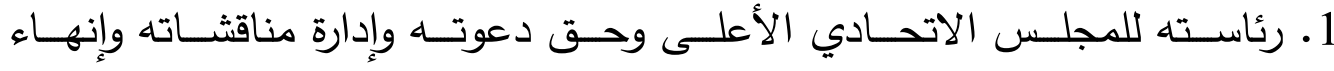
اجتماعاته. 2. الدعوة لاجتماع مشترك بين المجلس الأعلى ومجلس الوزراء.

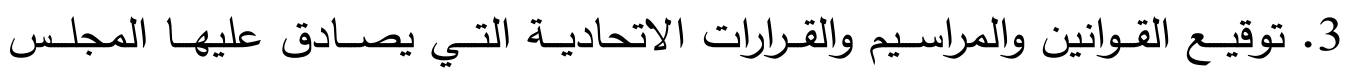
الاتحادي الأعلى. 4. تعيين رئيس مجلس وزراء الاتحاد، وقبول استقالته، وإعفاوه نفسه من منصبه

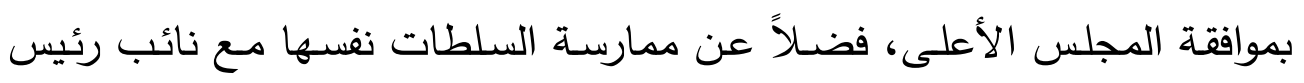
مجلس وزراء الاتحاد.

5. تعيين الممثلين الدبلوماسيين للاتحاد لدى الدول، وغيرهم من كبار الموظفين الاتحاديين والعسكريين ويقبل استقالتهم وعزلهم بناء على موافقة مجلس وزراء 
6. يوقع أوراق اعتماد الممثلين الدبلوماسيين للاتحاد لدى الدول والهيئات الأجنبية

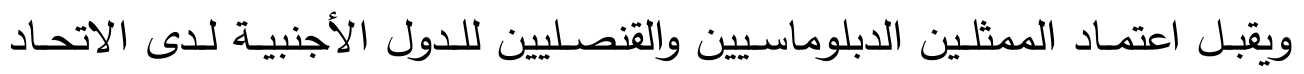
ويتلقى أوراق اعتمادهم.

7. الإشـراف على تنفيذ القوانين والمراسيم والقـرارات الاتحاديـة بوسـاطة مجلس وزراء الاتحاد والوزراء المختصين. 8. يمثل الاتحساد في الداخل والخـارج، بوصفه رئيس الدولـة وهو رمـز السلطة العامة في دولته، وهو الذي يمثلها باعتبارها وحدة سياسية في الداخل والخارج وتتظيم علاقاتها مع الدول الأخرى بواسطة وزير الخارجية . 9. ممارسـة حق العفو أو تخفيف العقوبـات ويصـادق على أحكام الإعدام وفقاً لأحكام هذا الدستور والقوانين الاتحادية.

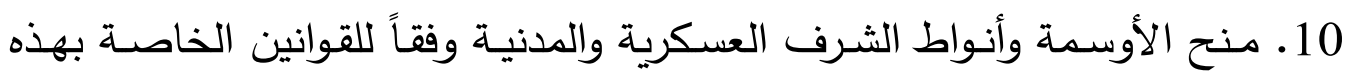
الأنواط.

11. أيـة اختصاصـات أخرى يخولـه إياها المجلس الأعلى أو تخول له بمقتضى أحكام هذا الدستور أو القوانين الاتحادية.

ج : مجلس الوزراء

يشكل مجلس الوزراء الركن الثالث الأساسي في السلطة التنفيذيـة في دولـة الإمارات العربية المتحدة، والمجلس مسؤول في صـلاحياته صـلاحية كاملة أمام رئيس الدولة الاتحادية والمجلس الأعلى للاتحاد ويتكون مجلس الوزراء الاتحادي من رئيس المجلس الذي يعين بموافقـة المجلس الأعلى للاتحساد ونائبه وعدد مـن الوزراء ويتم تعيينهم بمرسوم من رئيس الاتحاد (55) . يتولى مجلس الـوزراء بوصففه هيئة تنفيذيـة للاتحساد، تصـريف جميـع الثـؤون

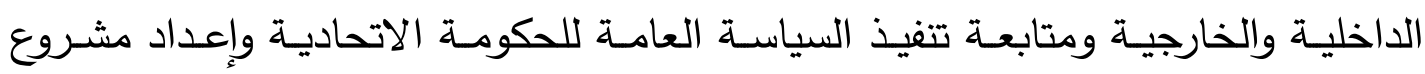
الميزانية السنوية العامة للاتحاد والحساب الختامي وإعداد مشروعات المراسيم والقرارات المختلفة والإشراف على تتفيذ القوانين والمراسيم واللوائح والقرارات الاتحادية والإشراف

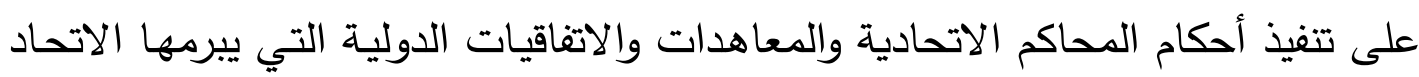
وغيرها من المهام والصلاحيات والمسؤوليات الأخرى(56). 
فيما يتعلق بالثؤون الخارجية فالمجلس يختص بالاتي (57): 1. متابعة تتفيذ السياسة العامة لحكومة الاتحاد في الداخل والخارج. 2. الإشراف على تتفيذ المعاهدات والاتفاقيات الدولية التي يبرمها الاتحاد . 3. تقديم تقرير مفصل إلى رئيس الاتحاد لعرضسه على المجلس الأعلى، في بداية

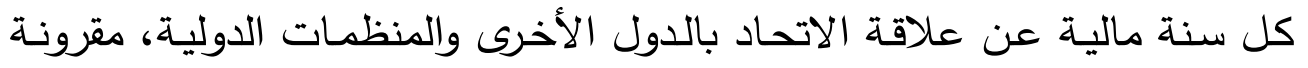
بتوصيات الوزارة عن أفضل الوسائل الكفيلة بتوطيد أركان الاتحاد وتعزيز أمنه

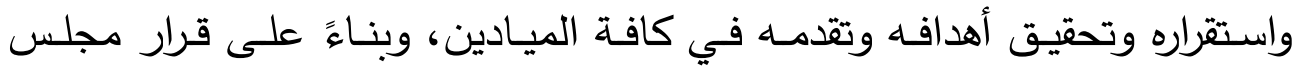
الوزراء رقم (6) لسـنة (2001)، تمت الموافقـة على الهيكل التنظيمي لـوزارة

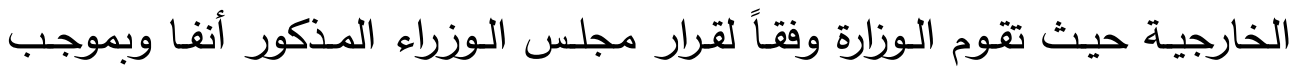
المـادة الثانيـة مـن هـذا القـرار بوضـع الاقتراحسات اللازمـة لتخطـيط السياســة

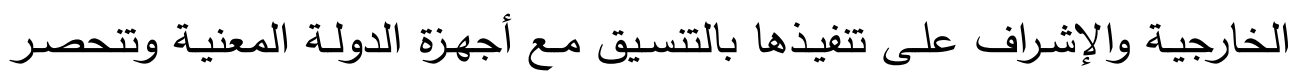
اختصاصاتها بما يأتي (58) :

1. الإشـراف على جميع علاقات الدولـة بالدول الأخرى، وتتظيم وتبـادل التمثيل

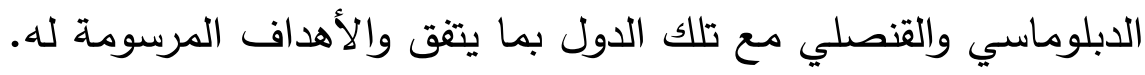
2. الاشتراك في جميع الدفاوضات المتعلقة بالعلاقات الخارجية . 3. تنظيم اشتراك الدولة في المؤتمرات والمنظمات أو المعارض الدولية والإقليمية. 4. حماية مصالح الدولة ورعاياها في الخارج.

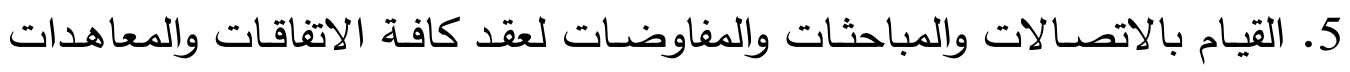
التي ترغب الدولة ان تكون طرفاً فيها، والقيام بالإجراءات اللازمـة للانضمام إلى الاتفاقيات والمعاهدات الدولية التي تقرر الانضمام إليها، والإثراف على ترك

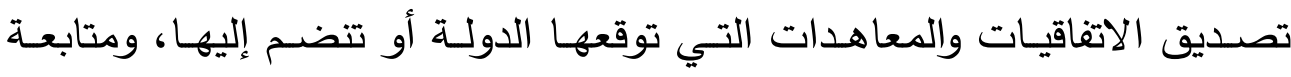
تتفيذ الاتفاقيات والمعاهدات وتفسيرها ونقضها ويتم ذلك بالاشتراك مع الجهات الأخرى المعنية في الدولة وفقاً لإحكام الدستور والقانون.

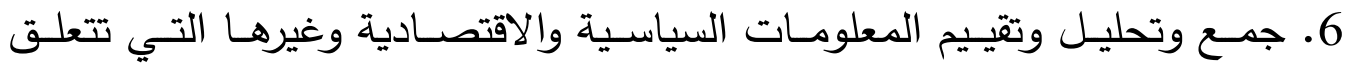
بالتطورات المؤثرة على العلاقات الخارجيـة للدولة وتوزيع البيانات والمعلومات على جهات الاختصاص. 
7. تتظيم الاتصـالات بـين وزارت الدولــة ومصــالحها ودوائرهـا، وبـين الهيئـات

والحكومات الأخرى وبعثاتها التمثيلية.

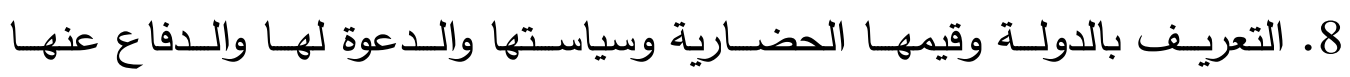

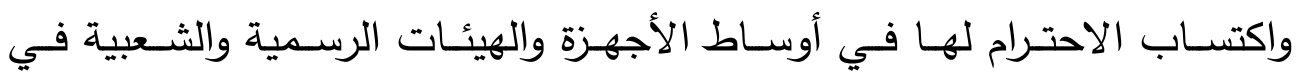
الخارج.

9. القيام بأعمـال المزايـا والحصـانات والمراسم للبعثات التمثيلية للدولـة ورؤسـائها

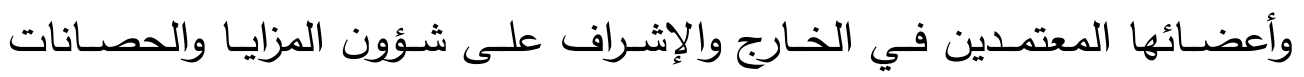

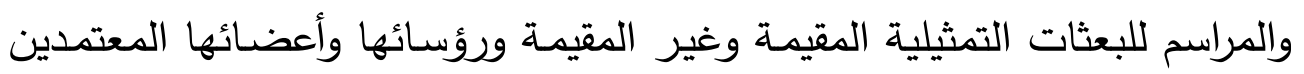

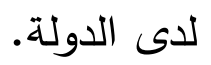

10. إصدار وتحديد جوازات السفر العادية للمواطنين في الخارج وفقاً للقواعد التي تقررها وزارة الداخلية، والتعليمات التي تصدرها وزارة الخارجية .

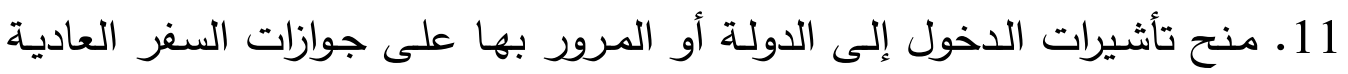

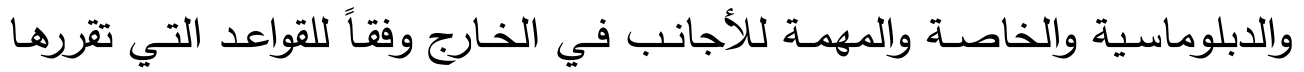

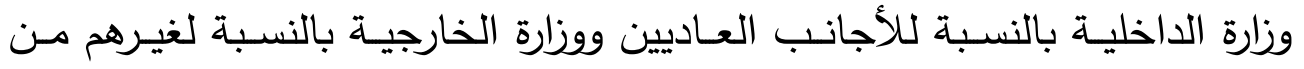
الأجانب.

12. إعداد وتوجيه التعليمات الدبلوماسية والقنصلية والإداريـة والمالية اللازمة لقيام البعثات التثيلية للدولة بأعمالها.

13. الأشراف على جميع ممثليات الدولة الدبلوماسية والقنصلية في الخارج . يقوم الهيكل التنظيمي لوزارة الخارجية وفق قرار مجلس الوزراء رقم (6) لسنة 2001 المادة (3) كالآتي (59): 1- الجهاز الرئيس ويتكون من:

الوزير - وزير الدولة للشؤون الخارجية

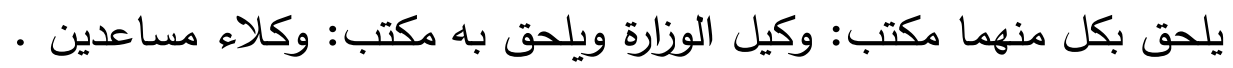

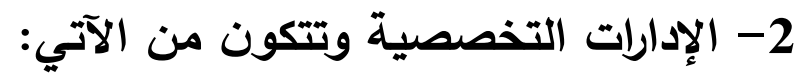
أ : إدارة شؤون مجلس التعاون ودول الخليج العربي

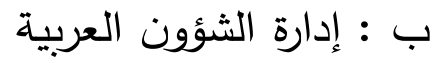


ج : إدارة الشؤون الآسيوية والأفريقية د : إدارة الثؤون الأوربية والأمريكية والاقيانوسية

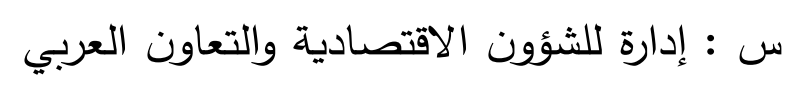
ص : إدارة الثؤون القانونية ط : إدارة للمنظمات والمؤتمرات ع : إدارة للشؤون الإعلامية وللدراسات والبحوث ف : إدارة للشؤون المالية ك : إدارة للشؤون الإدارية م : إدارة نظم المعلومات والاتصالات ن : إدارة المراسم هـ : إدارة للشؤون القنصلية و : المكاتب الفرعية للوزارة في الإمارات 3- الأجهزة الفرعية وتتكون من:

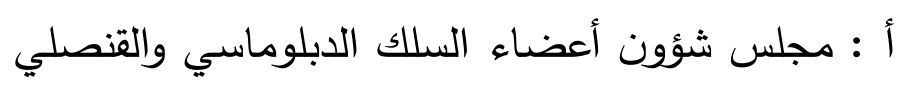

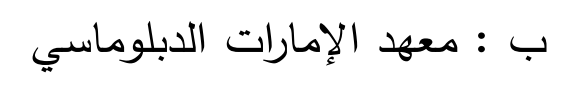
ج : مكتب الثؤون الأمنية د : لجنة شراء وتملك العقار الرسمية للبعثات في الخارج

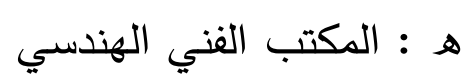
و : لجنة شؤون البعثات التعليمية.

4- البعثات التمثيلية للدولة لدى الدول الأخرى.. والهيئات الدولية والإقليمية.

قامـت وزارة الخارجيـة عـام 2002 بإعـداد هيكـل تنظيمسي جديــ للـوزارة بهـف

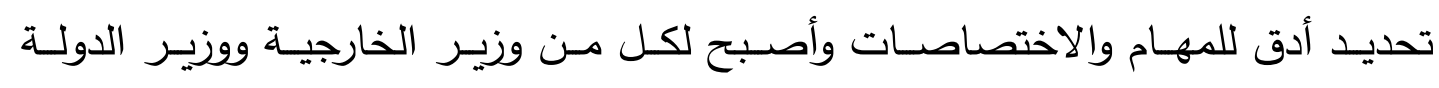

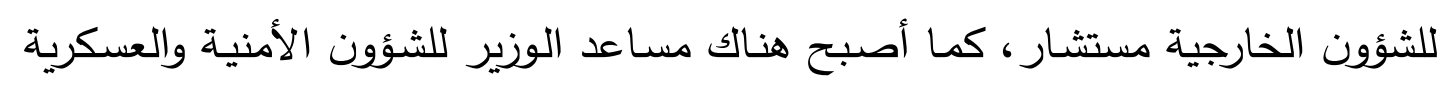

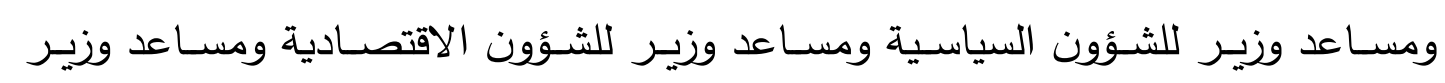

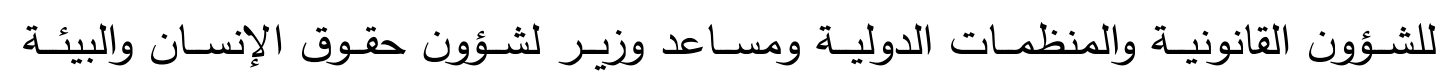
واستحدث منصب المدير العام وتم ربطه بعدة مكاتب هي: المكتب التنفيذي للشؤون الأنسان ولينية 
المتخصصــة و المكتب التنفيـذي لشـؤون المـوارد البشـرية والمائيـة ومكتب المـدير

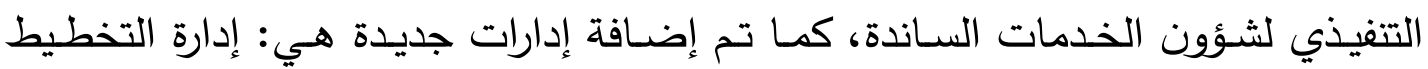

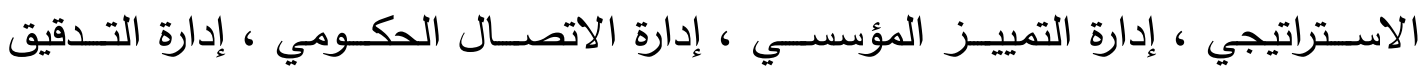

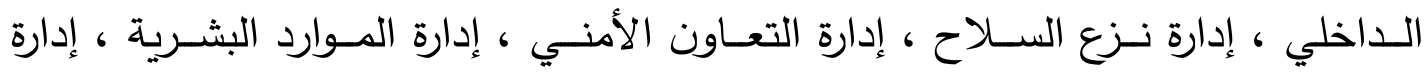

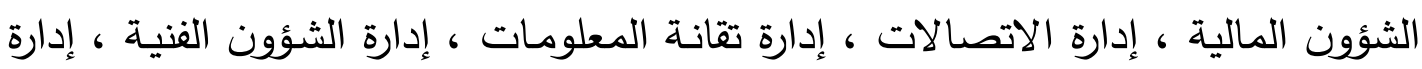
اللجان المشتركة، إدارة حقوق الإنسان، إدارة شؤون البيئة(60) .

ثالثآ :السلطة القضائية

تسهم السلطة القضائية بدور غير مباشـر في عملية صنع السياسية الخارجيـة

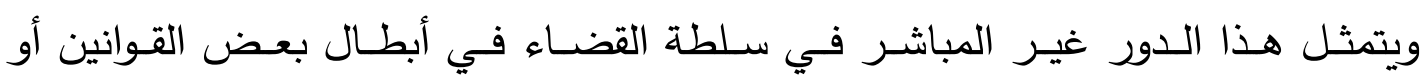

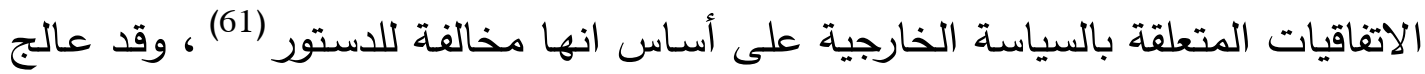

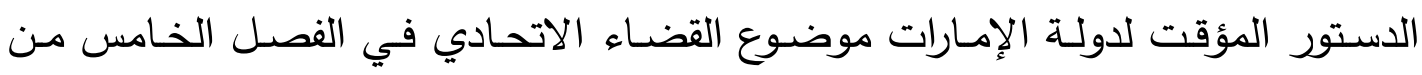

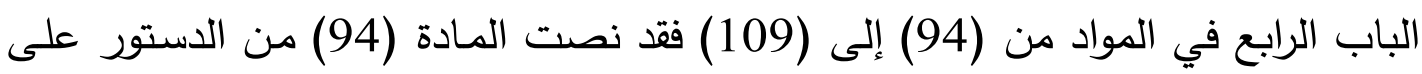

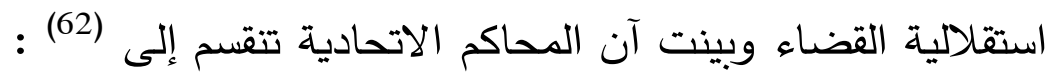

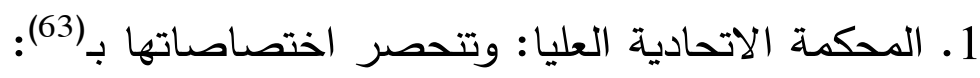
أ- تفسير الدستور وتفسيرها ملزم. ب- مراقبة دستورية القوانين، وأحكامها باتة ونهائية وملزمة للكافة.

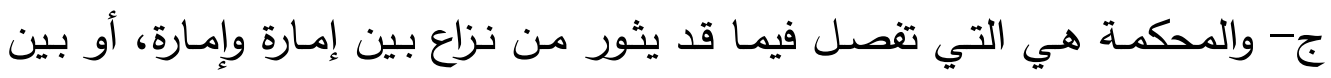

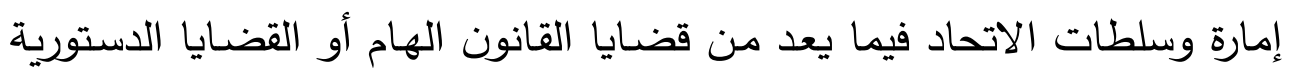
وأحكامها أيضاً ملزمة. د- هي التي تقضسي استئنافياً في كثير من أنواع القضـايا الصـادرة من محساكم الولايات، ومعنى ذلك أنها المرجع الأخير للقضاء.

$$
\begin{aligned}
& \text { هـ - هي التي تحاكم الوزراء. } \\
& \text { 2. محكمة الاستئناف. }
\end{aligned}
$$

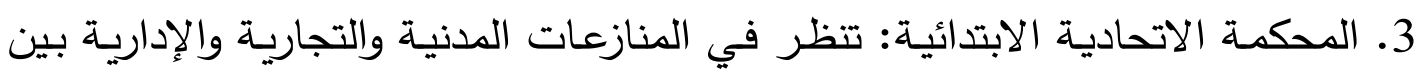

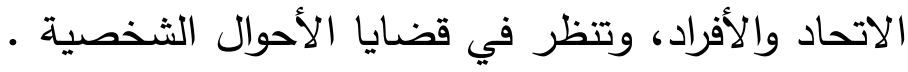

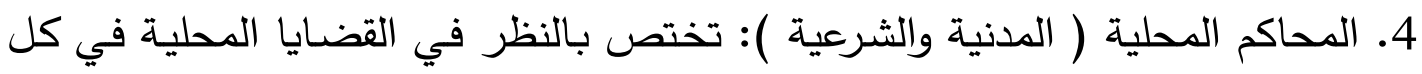
إمارة والتي لم يعهد بها إلى القضاء الاتحادي. 
من هنا نرى ان المحكمة الاتحادية العليا لها علاقة بموضوع السياسة الخارجية كونها تختص بالبحث والفصل في دستورية التشريعات الصادرة وتفسير أحكام الدستور ومساءلة الوزراء والجرائم التي لها مساس مباشر بمصالح الإتحاد.

المبحث الثاني: الهياكل غير الرسمية لصنع السياسة الخارجية الاماراتية

تتلخص الهياكل غير الرسمية بالمتغيرات التي تساعد في التأثير والتقاعل مع فع المؤسسات الرسمية في عملية صنع القرار وهي (64): 1. الأحزاب السياسية: بوصفها قنوات للمشاركة السياسية وأدوات لبلورة الخيارات والبدائل أمام صانعي القرار . 2. جماعات الضغط: كالنقابات ومنظمات المجتمع المدني.

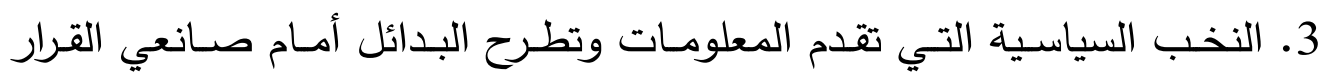

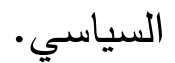
4. الرأي العـام: ويعد مقياس مهم لمـا تتطلـع إليهـ الثـعوب من آراء واتجاهـات

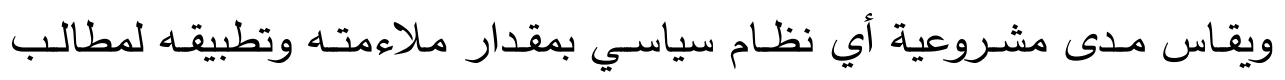

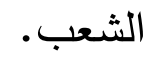

5. الصحافة ووسائل الإعلام: عند وجود صحافة حرة ووسائل إعلام فعالة تعبر

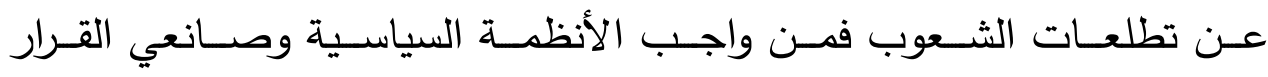

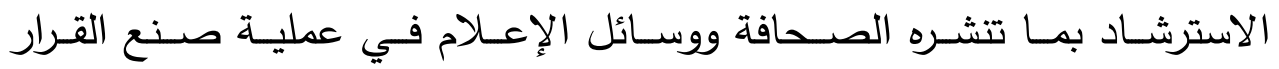
السياسي.

وفي دولة الإمارات العربية المتحدة نرى ان الهياكل غير الرسمية لا وجود فعلي

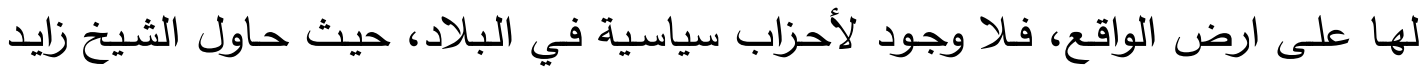

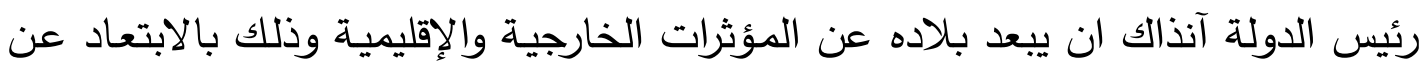

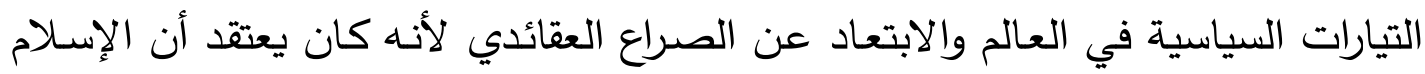

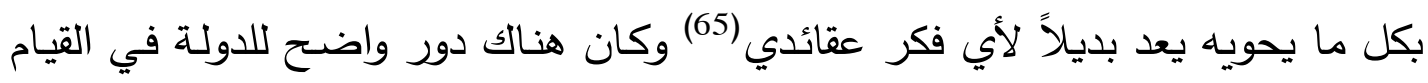

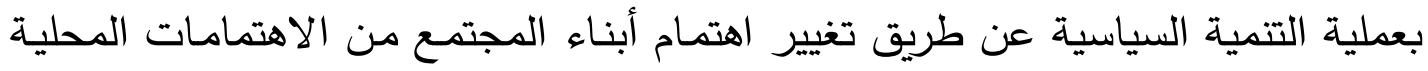

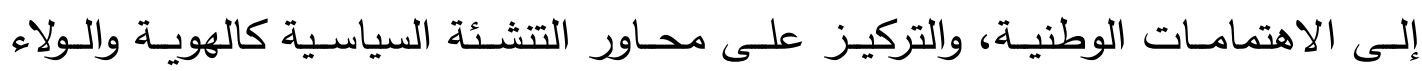

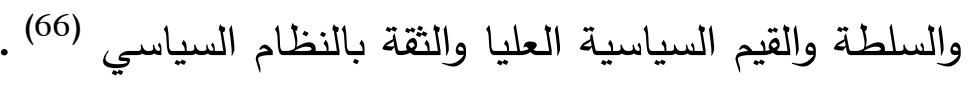


لكن هناك مجموعة من المنظمات المهنية التي تقدم خدمات اجتماعية في البلاد

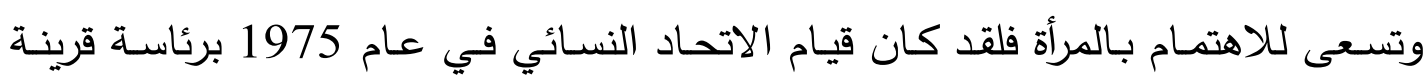

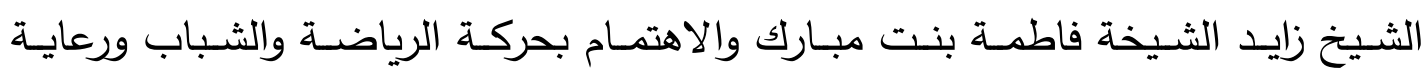

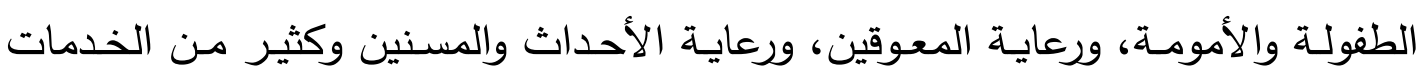

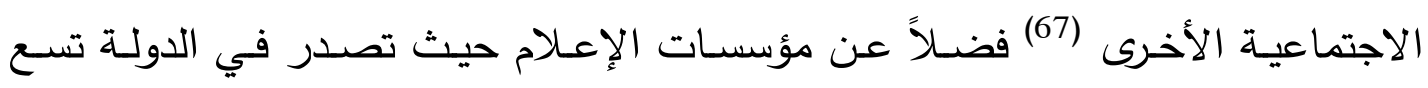

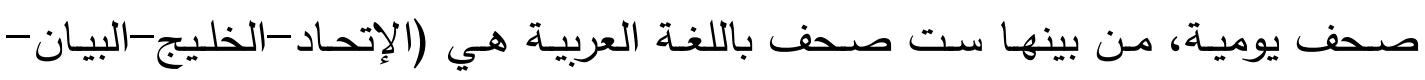

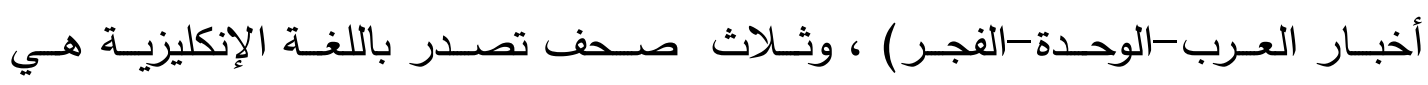
ووجود وكالات الأنباء المتطورة (Gulf News, Gulf Today, Gulf Times)

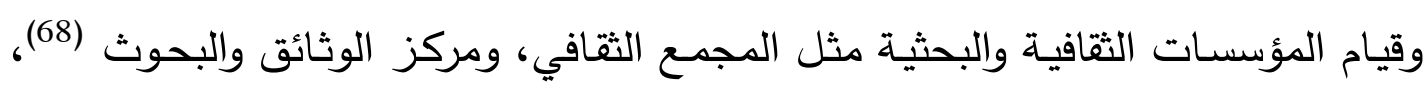

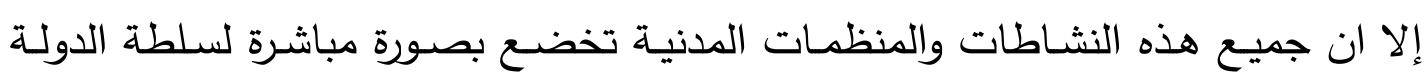

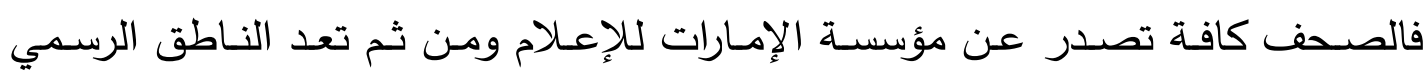

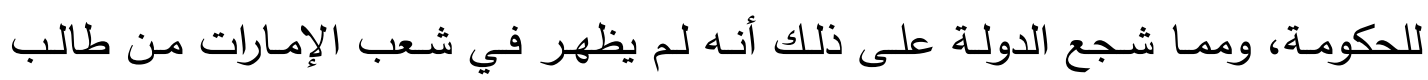

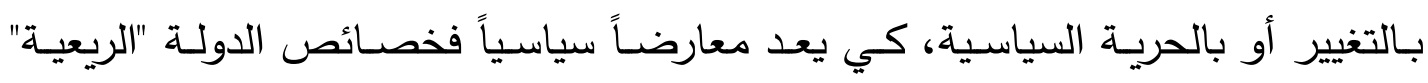

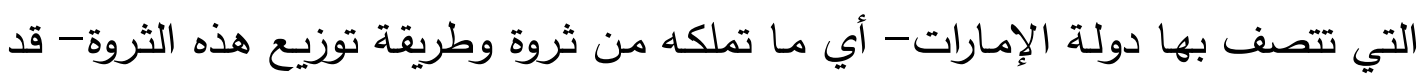

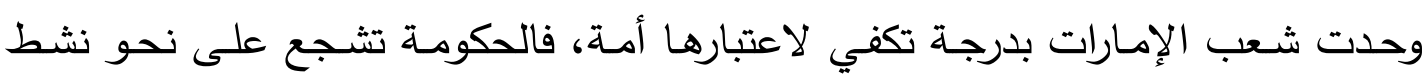

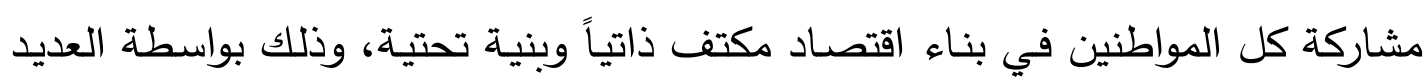
من المشروعات الرسمية فضلاً عن تشجيع أيدلوجية المؤسسات التجارية(69) ـ

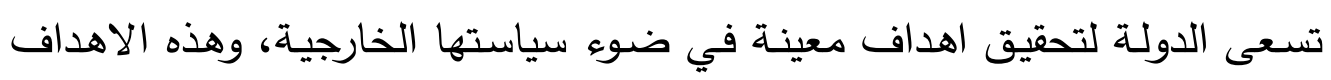
قد تكون مبدئية وثابتة نابعة من تاريخ وحضارة تلك الدولة، او قد تكون متغيرة حسب اهب

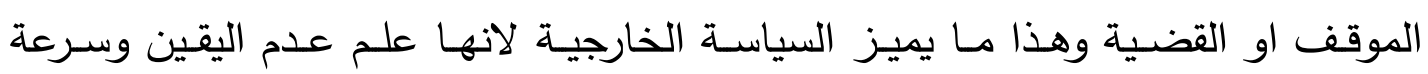
التغيير وعليه تقسم أهداف السياسة الخارجية بشكل عام حسب أهميتها وديمومتها إلى الى الى الهيل قسمين (70) :

1. أهداف دائمسة وهي التي لا تتغير على الأقل من حيث المعيـار النسبي إذا مـا

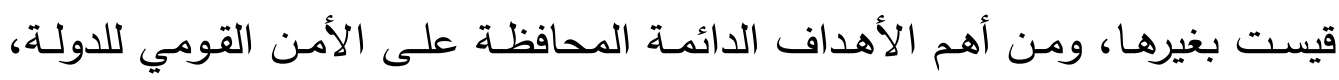
وهذا الهدف يشكل سلوك الدولة في مواجهة العالم الخارجي، فالأمن القومي في الاهدي التهني

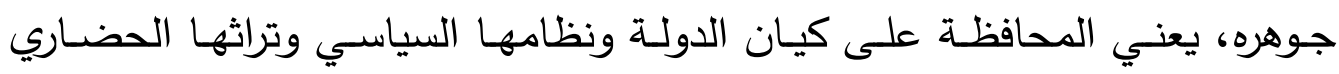
وطابعها القومي وتسخر الدولة كافة إمكانياتها المادية والمعنويـة للمحافظة عليهـ ونيه. 


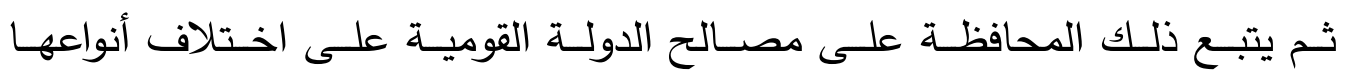
والمصالح هنا تأتي في المرتبة الثانية بعد الهدف القومي.

2. أهداف متغيرة: وهي التي ترتبط ببعض المواقف والقضايا سواء على المستوى

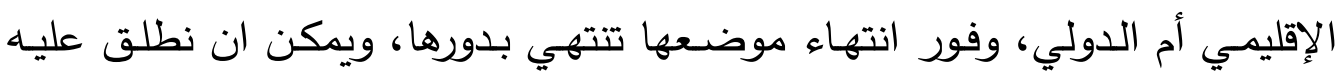

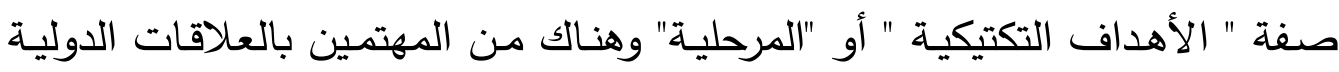
من صنف الأهداف السياسية للدولة على ثلاثة أهداف(71) :

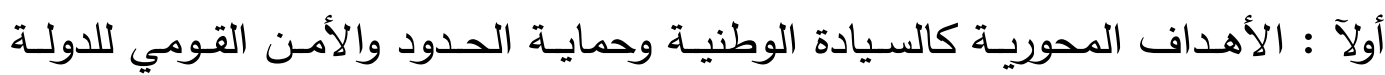
ووحدتها الوطنية.

ثانيـآ : الأهداف المتوسـطة: وهـي الأهداف التـي تصـفها الدولـة مـن أجلـ تحقيق

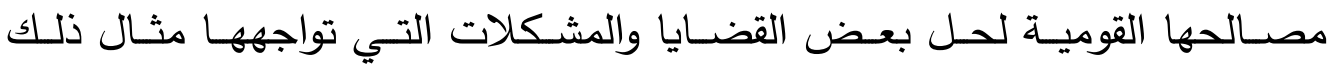
الأهداف المتعلقة ببناء النفوذ السياسي في العلاقات الدولية والاسهام بدور كبير في المحيط الخارجي، كذلك خدمة المصالح العامة للدولة.

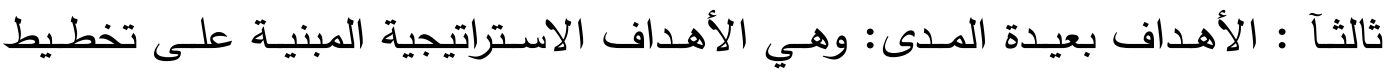
مدروس. وبغض النظر عـن التصـنيف فـإن دولــة الإمـارات العربيـة المتحدة تسـتند في

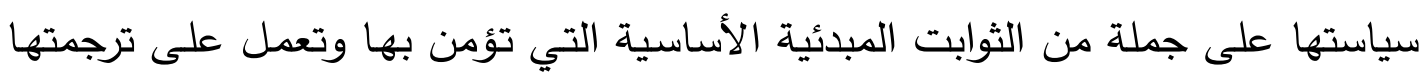

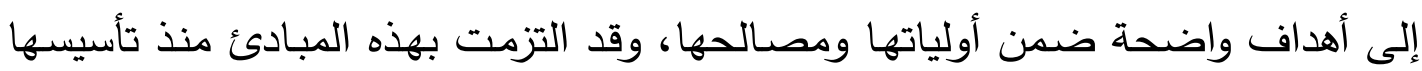
وحددت نهج سياستها الخارجية. لقد حدد الثيخ زايد بن سلطان آل نهيان رئيس دولية الإمارات العربية المتحدة أهداف السياسة الخارجية لدولته في كلمة ألقاها بمناسبة قيام دولة الإمارات في كانون الأول 1972 عندما قال:(72)" تتحرك أهداف سياستتا الخارجية في أربعة اتجاهات: أولاً: حل الخلافات بين دولة الإمـارات العربية المتحدة والدول المجاورة بالطرق الودية والسلمية. ثانياً: توسيع قاعدة الاتحساد وذلك بترك البـاب مفتوحاً أمـام دول المنطقـة التي تريــ الانضمام إليه. 
ثالثاً: دعم القضـايا العربيـة والتسنيق مـع الدول العربيـة الثقيقة في السياسية الخارجيـة والاقتصادية وفي كل المجالات.

رابعاً: الانفتاح على العالم ومشاركة جميع الدول في المجالات الدولية والالتزام بميثاق الأمم المتحدة، وستظل سياسة دولتتا تجاه العالم الإسـلامي ومشاركة فعالة في كل مـا يرفـع مـن شـأن الإسـاحم والمسـلمين " ، وعليـهـ نـرى اليـوم ان نهـج السياسـة الخارجيـة للدولـة ينطلـق مـن التزامهـا بانتمائهـا الخليجـي والعربـي والإسـلامي، وحرصـها على تعزيز وتوسيع دائرة صداقاتها مـع جميع دول العالم، والجنوح إلى حل النزاعات بالطرق السلمية، والالتزام بمواثيق الأمم المتحدة والمنظمات الإقليمية والدولية(73) •

\section{الخاتمة}

كانت الامارات تعيش حالة من الانعزال السياسي والانغلاق الاجتماعي، اذ كانت منقطعة سياسيا عن العالم الخارجي، وهذا من جراء المستعر البريطاني، الذي عزل البلاد عن كل مؤثرات المحيط الخارجي، فضـلاً عن قلة الامكانات والقدرات المادية والاقتصـادية لدولـة الامـارات في مرحلـة مـا قبل الاستقلال وقيام الاتحاد، وقد انتهى ذلك الانقطاع عن العالم بقيام الاتحاد والذي هو عبارة عن اتحاد فيدرالي، واندمجت الدولة الاتحادية بسرعة مع المحيط الخليجي والعربي والدولي. لقد صيغت العلاقة بين الامارات الأعضاء توافقيا وتم على ضوء ذلك وضع دستور مؤقت للبلاد واختير الثيخ زايد بن سلطان آل نهيان رئيسا للاتحاد. استمر العمل بالدستور المؤت الى عام 1996 حيث ابدل بالدستور الدائم، ولم يتم تغيير أي نص أو بند من بنوده سوى حذف كلمة المؤقت واستبدالها بالدائم. انحسرت السياسة الخارجية بيد رئيس الاتحاد وبشخصه فقط، ويتم الامر بالتشاور بين رؤوساء الامارات والمشايخ ورئيس الاتحاد والكلمة الاخيرة تبقى لرئيس الاتحاد، واستمر الحال كذلك الى ان صدر قرار اتحادي بتشكيل جهاز تتظيمي لوزارة الخارجية عام 2001. 


\section{الهوامش والمصادر}

(1) أحمد خليل عطوي، دولـة الإمـارات العربيـة المتحدة نشـأتها وتطورهـا، المكتب التجـاري

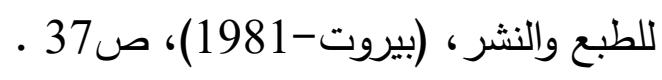

(2) محمد سعيد اللخام، موسوعة دول واقاليم العالم، ط1، المجلد الاول، دار نوبليس، (بيروت-

$$
\text { 2009)، صن30 }
$$

(3) صلاح الدين محمد حسن الحفيد، "القطاع الزراعي وآفاق تطوره في دولة الإمارات العربية

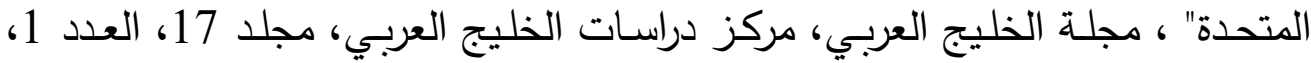

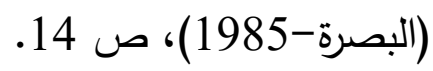

(4) ابتسام عبد الأمير حسون، دولة الإمـارات العربية الدتحدة دراسة في الأحوال السياسية

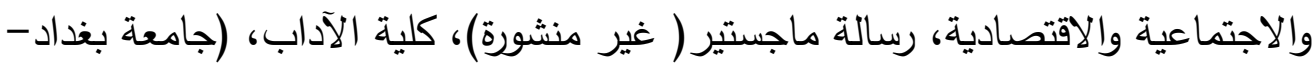

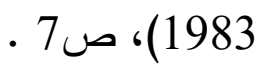

(5) مانع سعيد العتيبة، البترول واقتصاديات الإمارات العربية الدتحدة، دار القيس، (الكويت-

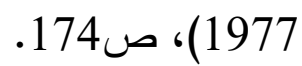

(6) عطوي، المصدر السابق، ص ص 82-83 ؛ فالحة صالح احمد الصالح ، سياسة دولة الامارات العربية المتحدة الخارجية تجاه منطقة الخليج العربي 1991-2003 ، أطروحة

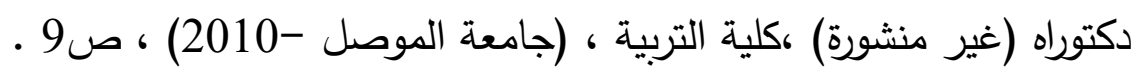

(7) عبد الرحمن النعيمي، " الوحدة والصراع في الخليج العربي"، مجلة دراسات عربية، دار 16 10 الع

$$
\text { (بيروت-1980)، ص141) }
$$

(8) المصدر نفسه، ص142 ؛ الصالح ، المصدر السابق ، ص99 .

(9) مصطفى عبد القادر النجار ، دراسات في تاريخ الخليج العربي المعاصر ، معهد البحوث

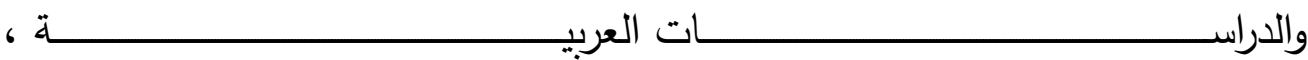

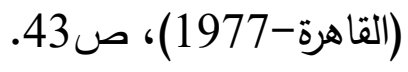

(10) حسون، المصدر السابق، ص 36 ؛ الصالح ، المصدر السابق ، ص 10 . 
(11) عطوي، المصدر السابق، ص 96 ؛ الصالح ، المصدر السابق ، ص 10 ـ

(12) ر. م • بوريـل، الخليج العربي، ترجمـة مكي حبيب المؤمن، مطبعـة الرشـاد (بغداد-

$$
\text { . 1977) ص • } 193
$$

Hassan Al-samrrai and Abdel mouuti souwed, Emirates and Gee (13) Society, university Book House (Alain-2006), P 43.

(14) نادر فرجاني، الهجرة إلى النفط أبعاد الهجرة للعمل في البلدان النفطية وأثرها على التتمية

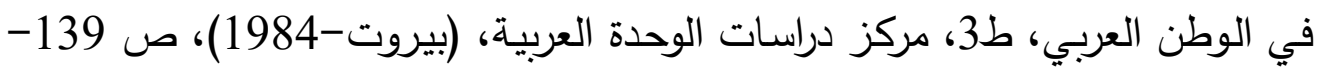

166؛ الصالح ، الدصدر السابق ، ص 10 ـ

(15) معن خليل عمر، مجتمع الإمارات والمفاعيل العملاقة، دار الكتاب الجامعي، (العين -

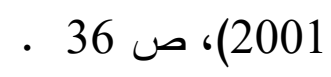

(16) اسكندر بشير، دولـة الإمـارات العربيـة المتحدة، مسيرة الاتحساد ومستقبله، دار الكتاب

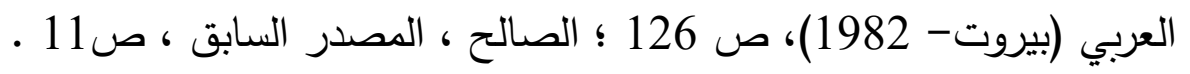

(17) نـايف علـي عبيـد، السياسـة الخارجيـة لدوبـة الإمـارات العربيـة المتحـدة بـين النظريــة

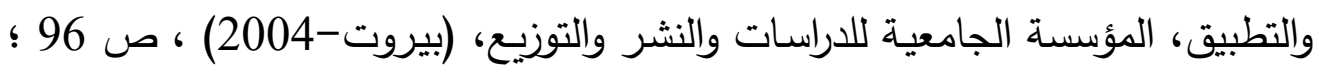

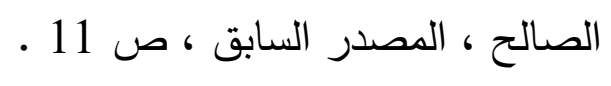

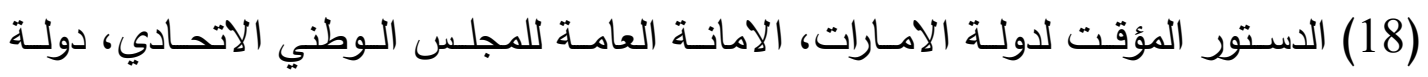

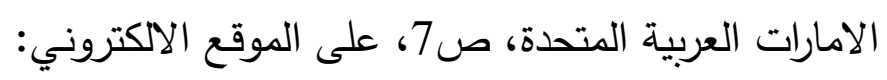

$\underline{\text { www.Emiratesmediastudiescenter }}$

(19) التقرير السنوي لدولة الإمارات العربية المتحدة، وزارة الإعلام، (الامارات-1974)، ص ، صل

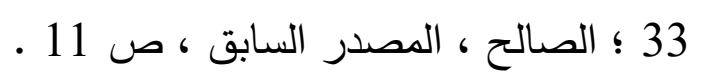

(20) لمعرفـة التفاصيل ينظر : فالحسة صـالح أحمد الصـالح، سياسـة دولـة الإمـارات العربيـة

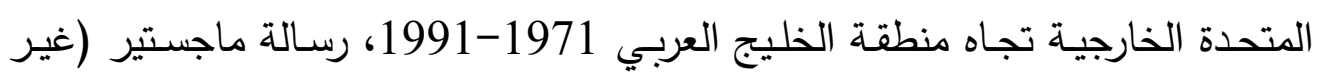

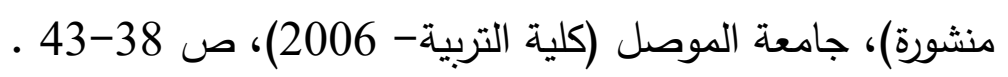

$$
\text { (22) عمر ، الدصدر السابق، صبدر السابق، ص39. }
$$


(23) على الدين هلال و نيفين مسعد، النظم السياسية العربية قضايا الاستمرار والتغير، مركز

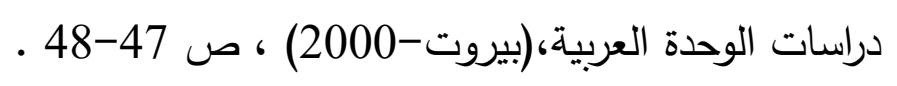

(24) يحيى الجمل، "الدستور وسيلة للتكامل في دولـة الإمـارات "، في مجموعـة باحثين،

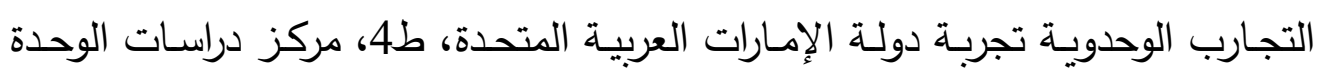

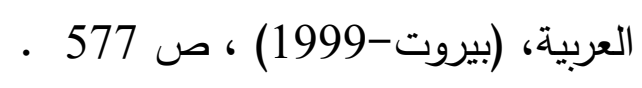

(25) حسـن حمــان العلكيم، "السياســة الخارجيـة لدوبـة الإمـارات العربيـة المتحـدة خـلال

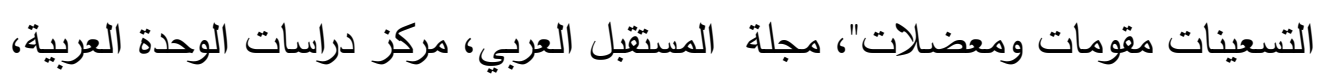

$$
\text { السنة 15، العدد 169، (بيروت-1993)، ص صدات } 69
$$

(26) محم فتوح حمح عثمان، رئيس الدولة في النظام الفيدرالي، الهيئة المصرية العامة للكتاب

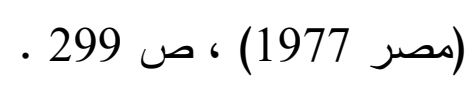

(27) عبد الله عمران تريم، " تأملات في واقع ومستقبل دولة الإمارات العربية المتحدة" ، في

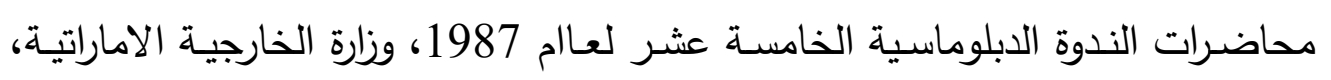

$$
\begin{aligned}
& \text { (ابو ظبي- 1987)، ص } 21 \text {. } \\
& \text { (28) المصدر نفسه، ص } 20 \text {. } \\
& \text { (29) العلكيم، المصدر السابق، ص } 70 \text { ـ }
\end{aligned}
$$

(30) الكتاب السـنوي لدولــة الإمـارات العربيـة المتحـدة، وزارة الإعـام والثتقافـة، (الإمــارات-

$$
\text { . 2004)، ص } 58
$$

(31) محمد إبراهيم، اسس التتظيم السياسي والدستوري لدولـة الإمـارات العربـة المتحدة، مركز

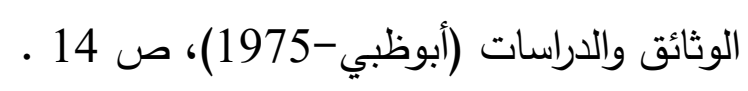

(32) العلكيم، المصدر السابق، ص 69 ـ .

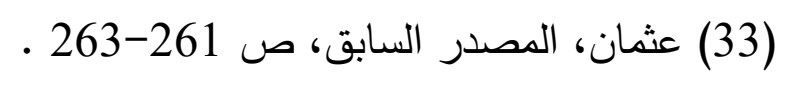

(34) أحمد عبد الله بـن سعيد، البعد العربي في السياسـة الخارجيـة لدولـة الإمـارات العربيـة

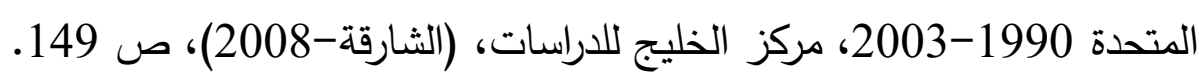

(35) محم السيد سليم، تحليل السياسة الخارجية، دار الجيل، (بيروت-2001)، ص 453 ـ

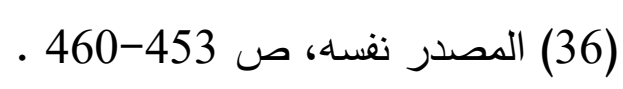


(37) عبـد الوهـاب الكيـالي، الموسـوعة السياسـية، ج3 ، ط3، المؤسسـة العربيـة للدراســات

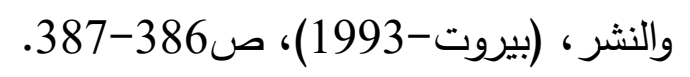

(38) هاني الياس خضر الحديثي، في عملية صنع القرار السياسي الخـارجي، دار الرشيد

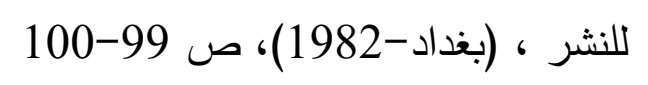

(39) إبراهيم، المصدر السابق، ص 207 ـ

(40) بطرس بطرس غالي ومحمود خيري عيسى، المدخل في علم السياسية، ط2، مطابع

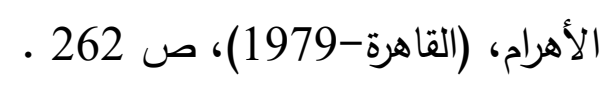

(41) الدستور المؤقت لدولة الامارات، المصدر السابق، ص 9 .

(42) المصدر نفساه، ص9 9.

(43) مجتمع الإمـارات، المذكرة المقررة 2002-2003، جامعـة عجمـان للعلوم والتكنلوجيا،

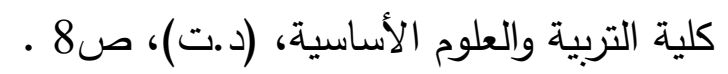

(44) المصدر نفسه، ص 8 (45)

(45) الدستور المؤقت لدولة الامارات، الدصدر السابق، المواد 89، 90، 91، 92، ص10 ـ

(46) الجمل، المصدر السابق، ص 600 .

(47) سليم ، المصدر السابق، ص 453 .

• 455 (48) المصدر نفسه، صل

(49) سليم، المصدر السابق، ص 454 .

(50) الدستور المؤقت لدولة الإمارات، المصدر السابق، صك.

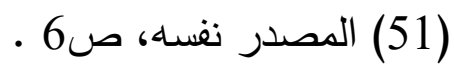

(52)عثمان، المصدر السابق، ص 278 ـ (52)

(53) الدستور المؤقت لدولة الإمارات، المصدر السابق، صكاس .

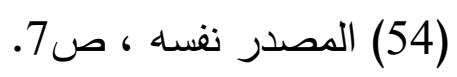

(55) بن سعيد، المصدر السابق، ص 153 ـ

(56) ينظر المادة (60) من الدستور المؤقت لدولة الإمارات،المصدر السابق، صل7. 
(57) عبيد، الدصدر السابق، ص 92 .

(58) المصدر نفسه ، ص 121-122 .

(59) المصدر نفسه ، ص123-124.

(60) الصالح ، الدصدر السابق ، ص 12 .

(61) السليم، المصدر السابق، ص 461 .

(62) مجتمع الإمارات، المصدر السابق، ص82)

(63) الجمل، المصدر السابق، ص 601 .

(64) هلال ومسعد ، المصدر السابق، ص 48 .

(65) مركز التوثيق الإعلامي، زايد فكر ...وعمل، دولة الإمارات العربية المتحدة، (أبو ظبي-

$$
\text { 1984)، ص } 256
$$

(66) مجتمع الإمارات، المصدر السابق، صنا 61 .

(67) للمزيد ينظر : خالد بن حمح القاسمي، التاريخ الحديث والمعاصر لدولة الإمارات العربية

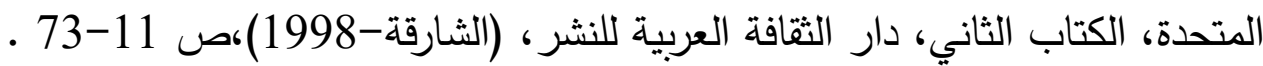

(68) التقرير السنوي عام 2004، المصدر السابق، ص 256-259 ـ

(69) سالي فندلو، دولة الإمارات العربية المتحدة الوطنية والهوية العربية-الإسلامية ، مركز

الإمارات للدراسات والبحوث الإستراتيجية، (أبو ظبي - 2001) ، صل 30 ـ 30 ـ

، (70) عبيد ، المصدر السابق، ص 27 (

(71) ناصـيف يوسـف حتي، النظريـة في العلاقـات الدوليـة، دار الكتاب العربي،(بيـروت-

$$
\text { . 1985)، ص } 90
$$

(72) عبيد، المصدر السابق، ص 107 ـ

(73) الكتاب السنوي لعام 2004، الدصدر السابق، ص70 . 